\title{
RISK MANAGEMENT AND CORPORATE VALUE
}

\author{
Milan Cupic* \\ Faculty of Economics, University of Kragujevac, Kragujevac, The Republic of Serbia
}

\begin{abstract}
The paper presents a theoretical framework for assessing the impact of risk management on corporate value. As the relevant factors that determine this impact, the paper analyzes market imperfections and investors' risk aversion. The results of the present research indicate that risk management contributes to an increase in corporate value if, under the influence of market imperfections, corporate risk exposure is concave. As an expression of market imperfections, the paper analyzes the costs of financial distress, agency costs, and taxation. The results of the research also indicate that the risk management policy should not aim to minimize, but rather optimize risk exposure, by taking into account the costs of risk management, investors' risk aversion and the competitive advantage a corporation has on the relevant market.
\end{abstract}

Keywords: risk management, corporate value, risk exposure, market imperfections, risk aversion

\section{JEL Classification: G14, G32}

\section{INTRODUCTION}

Financial risk can be defined as the volatility or uncertainty of the future cash flows of a firm, or the probability of the occurrence of an adverse outcome. It can be caused by different factors, although the financial literature usually analyzes the impact of unexpected changes in market prices (exchange rates, interest rates, commodity prices etc.) on the cash flows of a firm. Risk management includes an assessment of the risks that affect the cash flows of a firm and the implementation of appropriate strategies to control these risks. The objective of risk management, depending on the degree of investors' and managers' risk aversion, can be defined as maintaining cash-

\footnotetext{
* Correspondence to: M. Cupic, Faculty of Economics, University of Kragujevac, D. Pucara 3, 34000 Kragujevac, the Republic of Serbia; e-mail: mcupic@kg.ac.rs
}

flow changes within a certain range or minimizing these changes. Risk management strategies can be financial, if they involve the use of financial derivatives (forwards, futures, options etc.); or operational, if they involve the development of business flexibility and diversification. Risk management is financially justified if it contributes to an increase in firm value, determined by discounting the expected free cash flow of a firm.

Empirical studies show that firms usually manage risk, and invest most of the efforts in the management of foreign-exchange and interest rate risks (Bodnar \& Gebhardt, 1999; Brown, Crabb \& Haushalter, 2006; Aretz \& Bartram, 2010). Firms usually manage risks of current transactions and use financial derivatives, paying less attention to risks of future transactions, so that they rarely use operational risk management 
strategies (Stulz, 1996; Joseph, 2000). However, it should be borne in mind that risk management is often not a matter of choice or a strategic orientation of a firm, but rather a response to requirements set out in guidelines of international organizations (for example, Organization for Economic Cooperation and Development, 2015) and capital markets (for example, The New York Stock Exchange, 2013), as well as in legal regulations (for example, Sarbanes-Oxley Act of 2002). These requirements are a reflection of efforts made to protect investors' interests, whereby no account is taken of financial effects of risk management. Accordingly, although empirical data on the prevalence of risk management could be interpreted as a reflection of the belief that risk management contributes to an increase in firm value, it is possible that firms manage risk for other reasons.

The subject of the theoretical research presented in this paper is the impact of risk management on corporate value. Following the previous research (Smith \& Stulz, 1985; Fatemi \& Luft, 2002; Meulbroek, 2002), the paper analyzes market imperfections and investors' risk aversion as the relevant factors that determine this impact. The paper specifically addresses the problem of defining the optimal (acceptable) level of risk exposure, which has been the subject of several theoretical and empirical studies (Shin \& Stulz, 2000; Nocco \& Stulz, 2006).

The aim of the paper is to review and analyze the conclusions of previous theoretical studies in order to indicate the complexity of the problem of the financial assessment of risk management decisions at the corporate level and create a basis for the development of guidelines that will help managers to make informed decisions concerning risk management.

Based on the findings of the previous theoretical research, the following two research hypotheses were established:

H1: Risk management can contribute to an increase in corporate value only if corporate value is the concave function of market prices.

H2: Risk management can contribute to maximizing corporate value if it keeps risk exposure at an optimal level, where benefits are greater than costs of risk management.

The research will be conducted through a qualitative analysis of the results of the previous theoretical research, which will allow drawing conclusions through theoretical generalization.

The paper is structured as follows: the first part of the paper presents the evolution of theoretical views on financial effects of risk management at the corporate level. In the second part, the influence of the form of the relationship between corporate value and market prices on the financial effects of risk management is the subject of the analysis, while in the third part the focus is put on expected effects (benefits) of risk management. In the fourth part of the paper, the problem of defining an optimal level of risk exposure is considered, while in the fifth part, the conclusions and the directions for future research are presented.

\section{THE EVOLUTION OF THEORETICAL VIEWS ON RISK MANAGEMENT}

From the early twentieth century to the 1970s, the dominant view in financial theory was that corporations did not need to manage risks of their operations since they had a large number of owners who had a small ownership stake and bore a small part of the total corporate risk. If they had diversified their investment portfolio, i.e. if they invested available funds in several investment alternatives with a negative correlation of expected cash flows (returns), investors would have been able to manage risk more successfully than corporations. A. A. Berle and G. C. Means (1932, 340-344) argued that risk management was financially justified only in firms owned by a single person (entrepreneur), who invested his/ her own capital and was entitled to net income as a compensation for risk management and risk taking. These authors claimed that corporations were created so that entrepreneurs could transfer their risks to a large number of small investors, and that corporations did not need to manage risk, but rather investors themselves should have managed risk according to their preferences. Investors had to be compensated 
for the risk taken when they invested their capital in a corporation, which was analogous to salaries that employees received for the supplying of labor.

The explained logic was theoretically formulated by F. Modigliani and M. H. Miller (1958), in the theorem which laid the foundation of modern corporate finance. Starting from the assumption of the absence of market imperfections, they claimed that the value was created by investments with a positive operating cash flow, whereby it was irrelevant how these investments were financed - from a debt or equity. In other words, financial decisions, including those concerning risk management, did not contribute to corporate value creation, but rather only determined the manner in which corporate value was distributed among investors (shareholders and creditors). Their view was that corporations did not need to manage risks because rational investors on an efficient market could do that more successfully by themselves. A similar view was expressed by W. Sharpe (1964) who developed the CAPM (Capital Asset Pricing Model) on the assumption that the corporation did not need to manage its business risks (unsystematic risks), but rather investors themselves needed to reduce the risk of their investment portfolio to the desired level by using diversification. Corporations needed to make decisions by taking into account only systematic (market) risk, i.e. the risk that could not be influenced (could not be reduced by risk management instruments), which determined a risk premium for investments in a corporation. Other authors, who independently developed their own versions of the CAPM (J. Traynor, J. Lintner, J. Mosin, and F. Black) by relying on $\mathrm{H}$. Markowitz's portfolio theory, had a similar attitude.

It should be noted that theories advocating that corporations should not manage risks are built on the assumption that the market is efficient and investors are rational. When an analysis takes into account factors inherent to the real business environment, i.e. market imperfections (for example, taxation, financial distress, agency costs) and real investors, such a view is hard to justify. Five years after the publication of their theorem, F. Modigliani and M. H. Miller (1963) admitted that, if an analysis took account of only one market imperfection - corporate income tax, the capital structure was no longer irrelevant, nor was risk management. S. C. Myers (1974) and S. C. Myers and N. Majluf (1984) pointed out that corporations with a high level of a risky debt and a high probability of financial distress (debt overhang) might face problems in obtaining additional capital to fund a new investment, especially in conditions of a high uncertainty. Risk management can contribute to an increase in corporate value by reducing the volatility of cash flows and the probability of financial distress, because a corporation will be able to obtain external sources of funding under more favorable terms and increase total investments.

The assumption of rational investors was developed within the framework of the expected utility theory, which explains individuals' decision-making process under risk and uncertainty, which lies in the basis of a number of important financial theories (for example, H. Markowitz's portfolio theory, the CAPM model). This theory is normative because it describes the rules that every rational and fully-informed individual should follow when making decisions. It is assumed that individuals have a uniformly concave utility function (an expression of risk aversion), representing their risk preferences, and always choose an alternative (for example, investment), with the highest expected utility (Jaksic, 2012). The expected utility theory eventually became the subject of criticism, the most famous of which was presented in the prospect theory by D. Kahneman and A. Tversky (Kahneman \& Tversky, 1979; Tversky \& Kahneman, 1992). This theory is descriptive because it describes how real individuals make decisions in a real business environment using available information. Having started from the assumption that individuals focused their attention on possible changes in wealth (the outcomes of their decisions) rather than on the total wealth, D. Kahneman and A. Tversky replaced the utility function of an individual's total wealth with the value function, defined on deviations of possible outcomes from the reference point (a status quo)

D. Kahneman and A. Tversky have shown that individuals react asymmetrically to gains and losses their risk aversion is higher in relation to gains than losses. If they have to choose between a probable and a certain gains, most individuals choose a certain gain, even when the expected value of this alternative is lower. This choice is consistent with the expected 
utility theory, because it expresses a concave utility (value) function of an individual, i.e. risk aversion (the first quadrant in Figure 1). When they need to choose between a probable and a certain loss, most individuals prefer a probable loss, even when the expected value of this alternative is lower. This means that individuals are risk-takers when it comes to losses, i.e. their utility (value) function is convex in relation to losses (the third quadrant in Figure 1). D. Kahneman and A. Tversky have also noticed that the utility (value) function of individuals is steeper for losses than gains (individuals are more sensitive to losses than to gains), which is the expression of investors' loss aversion (Figure 1). If these findings are applied to corporations, it can be expected that the demand for shares of a corporation that offers a more certain return will be greater than the demand for shares of a corporation that offers a less certain return, even when the expected return of the latter option is higher (Stephens, 2001, 38-39).

Different theoretical views on the role of the financial policy in the process of value creation and on investors' attitudes towards risk brought about the development of a modern paradigm of financial management. It relies on the basic Modigliani-Miller claim that corporations create value by investments with a positive net present

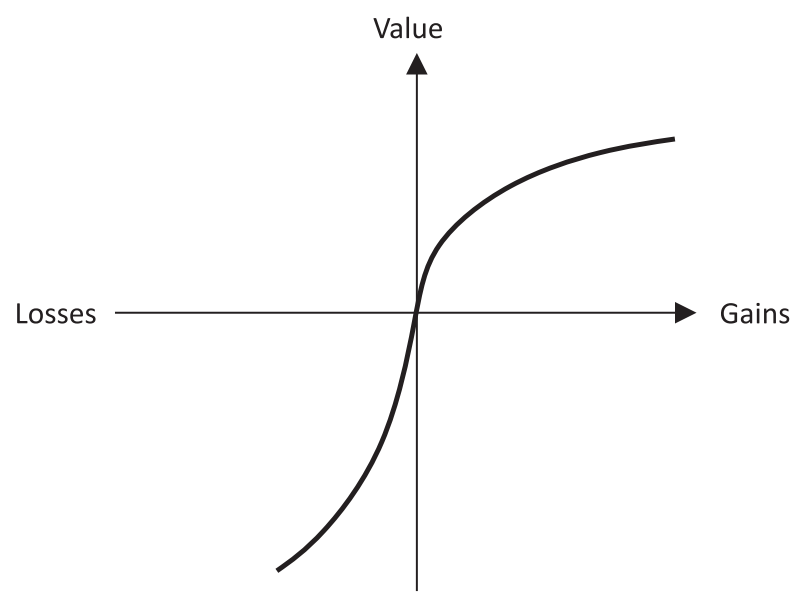

Figure 1 The value function according to prospect theory

Source: Kahneman \& Tversky, 1979 value of the expected cash flow from operations. This claim is supplemented by the view that the financial policy is a critical factor that indirectly contributes to an increase in corporate value because it allows a corporation to undertake investments that create value by providing less expensive funds. The role of the risk management policy, as a segment of the corporate financial policy, is to monitor and control the impact of changes in market prices (interest rates, foreign exchange rates etc.) and other factors on corporate cash flows and provide the stable financing of investments with a positive net present value (Froot, Scharfstein \& Stein, 1994). Risk management at the corporate level is even more significant, given the fact that individuals cannot be equally successful in risk management as corporations can, because they have less information (information asymmetry), must pay relatively higher costs of hedging, and are unable to reduce the risk and costs of bankruptcy (financial distress).

\section{RISK EXPOSURE AND RISK MANAGEMENT}

B. Dumas (1978) argued that risk exposure should be defined in terms of "what one has at risk". More specifically, risk exposure can be defined as the sensitivity of the value (book, market etc.) of a firm or certain items (assets, liabilities, income, costs, cash flows etc.) to random changes in some market prices (commodity prices, exchange rates, the interest rate etc.) at a certain point in the future. This means that risk exposure can be expressed as follows (Adler \& Dumas, 1984):

$V_{p}=E\left(\partial V / \partial p_{i}\right)$

Formula (1) defines risk exposure $\left(V_{p}\right)$ as the current expectation $(E)$ with respect to the partial sensitivity of the value of a firm or an item $(V)$ to future values of the price $i\left(p_{i}\right)$ ( $V$ is exposed to a number of prices). Exposure $V_{p}$ can be viewed as the slope of the curve that represents the relationship of $V$ and $p_{i}$ (the higher the exposure, the greater the slope of the curve). A positive (negative) value of $V_{p}$ indicates that $V$ increases with an increase (decrease) in $p_{i}$. Since risk exposure can be non-linear (convex or concave), the second- 
order partial derivative of the function $V$ enables an assessment of the form of the relationship between $V$ and $p_{i}$ :

$V_{p p}=E\left(\partial^{2} V / \partial p_{i}^{2}\right)$

A positive (negative) value of $V_{p p}$ indicates that $V_{p}$ is the convex (concave) function of $p_{i}$. When $V_{p p}=0$, then the relationship between $V$ and $p_{i}$ is linear. The generic types of concave exposure are: the quadratic function, the cubical function and the sinus hyperbolicus, and of convex exposure: the cubical root function and the inverse sinus hyperbolicus. The degree and form of risk exposure is usually evaluated by using regression models, i.e. by the assessment of partial regression coefficients (Adler \& Dumas, 1984; Bartram, 2004).

An impact of the form of the relationship between $p$ and $V$ on financial effects of risk management can be explained by using Jensen's inequality (Smith \& Stulz, 1985; MacKay \& Moeller, 2007). In its simplest form, this inequality proves that the convex (concave) function of the expected value of a random variable is smaller (greater) than the expected value of the convex (concave) function of a random variable. Accordingly, risk management does not increase firm value (risk exposure increases firm value) if $V_{p p}<0$, given that $V(\bar{p}) \leq E[V(p)]$, where $V(\bar{p})$ is firm value if expected prices are realized (a secure outcome), and $E[V(p)]$ is firm value if the realized prices depart from expected prices (risk exposure). Risk management is justified if $V_{p p}>0$, given that $V(\bar{p}) \geq E[V(p)]$. In this regard, P. MacKay and S. B. Moeller (2007) point out the fact that the value of risk management (VUR) can be determined as follows:

$V U R=V(\bar{p})-E[V(p)]=$

$=V(\bar{p})-\left(V(\bar{p})+\frac{1}{2} V_{p p} \sigma_{p p}\right)=-\frac{1}{2} V_{p p} \sigma_{p p}$

where $\sigma_{p p}$ is the standard deviation of the price $p_{i}$. $E[V(p)]$ is determined by the value $V(\bar{p})$ and changes in $V$ (additional gains or losses), caused by unexpected changes of $p_{i}$. Formula (3) indicates that VUR has a positive value if $V_{p p}<0$ (it always applies that $\sigma_{p p} \geq 0$ ), and that VUR increases with an increase in the concavity of the function $V(p)$ and the increased volatility of $p_{i}$. Given the fact that $V$ depends on a range of prices $p_{i^{\prime}}$ it is necessary to estimate the form of each function $V\left(p_{i}\right)$. Furthermore, since firm value is determined by expected cash inflows and outflows, whose relationship with changes in $p$ is positive (inflows and outflows increase with an increase in prices), it can be concluded that the impact of risk on $E[V(p)]$ will be positive (negative) if inflows are the convex (concave), and outflows the concave (convex) function of market prices.

The impact of the form of the relationship between $V$ and $p$ on financial effects of risk management can be further graphically explained. Figure 2 presents the basic forms of the relationship between changes in $p$ and $V$, where Figure 2 a) presents relationships under the assumption that $V_{p}$ has a positive value, and Figure $2 \mathrm{~b})$ relationships under the assumption that $V_{p}$ has a negative value. What follows is the analysis of the relationships in Figure 2 a) only, since the relationships in Figure $2 \mathrm{~b}$ ) differ only in the direction of the slope, rather than in the form of the relationship.

Line 3 in Figure 2 a) represents a linear risk exposure, which indicates that $V$ increases with an increase in $p$ to the same degree to which it decreases with a decrease in $p$ (a firm gains under favorable conditions as much as it loses under unfavorable conditions). Corporate value is determined by changes, rather than the volatility of $p$ (exposure equals one), so it can be concluded that risk management does not affect corporate value. $R$. Friberg (1999, 28-29), however, argues that an analysis of the impact of linear risk exposure on financial effects of risk management should include investors' attitudes towards risk. If a firm has only one owner, who is indifferent to risk (zero risk aversion), risk management will not contribute to an increase in firm value if exposure is linear. If the owner is risk averse, then he/she will be less satisfied with favorable outcomes, rather than unsatisfied with unfavorable ones. A risk-averse owner always favors a certain return against an uncertain return (if they are of an equal value), and risk management can contribute to an increase in firm value when exposure is linear (the owner prefers horizontal exposure). If a firm has a large number of owners, each of whom can diversify his/her own portfolio, risk management is again justified because firms have much more information 


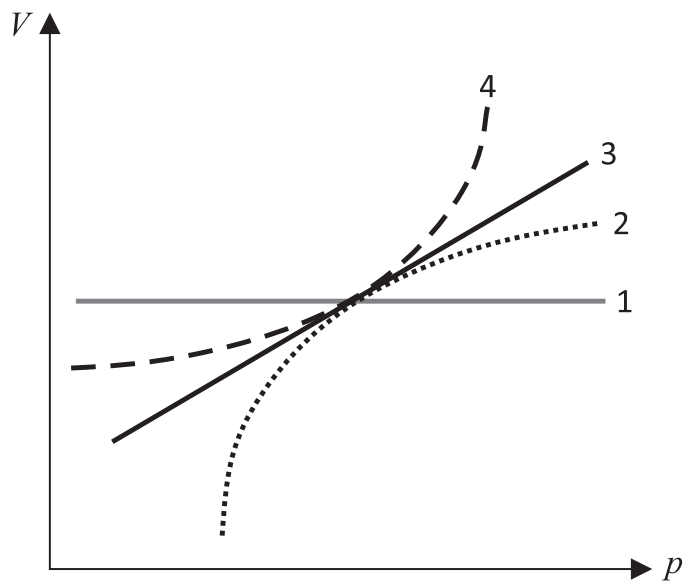

a) $V_{p}>0$

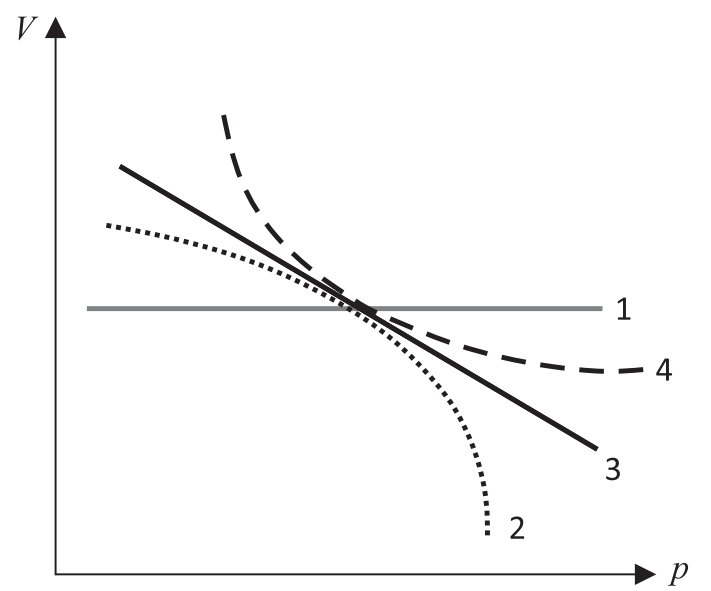

b) $V_{p}>0$

Figure 2 The basic relations between market prices and firm value

Source: Author, according to Friberg, 1999, 58

about risk exposure than investors do (asymmetric information). R. Friberg concludes that firms with linear risk exposure should manage risk, except in cases when their value is very large in comparison to their risk exposure (the total value of items exposed to risk).

Line 2 in Figure 2 a) represents the concave relationship between $V$ and $p$, which is most often the result of market imperfections (costs of financial distress, agency costs and taxation), whose influence on $V$ increases with an increase in the volatility of $V$. A concave relationship may also be the result of factors such as the declining utility of technology or an increasing marginal cost of production (Friberg, 1999, 26-28; Bartram, 2000). A concave relationship indicates that $V$ increases with an increase in $p$ to a lesser degree than it decreases with a decrease in $p$. In other words, in accordance with Jensen's inequality, $V$ decreases with an increase in the volatility of $p$, so that risk management may result in an increase in $V$.

As is shown in Figure 3, risk management increases the expected firm value from $E\left(V_{1}\right)$ to $E\left(V_{2}\right)$ and reduces the probability of financial distress (the left end of the distribution), due to the shifting of the probability distribution to the right and reducing the variations of $V$ (increasing the kurtosis).
The horizontal line 1 in Figure 2 a) represents a situation of the zero exposure of a firm $\left(V_{p}=0\right)$, which means that changes in $p$ have no influence on $V$. Line 4 in Figure 2 a) represents the convex relationship of $V$ and $p$, which indicates that $V$ increases with an increase in $p$ to a higher degree than it decreases with a decrease in $p$. This relationship limits the negative impact of unfavorable changes in $p$, so that $V$ increases with an increase in the volatility of $p$ (similar to financial options). A convex relationship may be caused by different factors, although it is usually caused by managerial flexibility (for example, a real option of expanding capacities), which allows the correction of past decisions or strategies in line with new circumstances. It can be concluded that risk management aims to stabilize cash flows and corporate value in order to reduce costs caused by market imperfections and replace concave exposure with a linear one, or increase managerial flexibility in order to achieve convex exposure.

\section{EFFECTS OF RISK MANAGEMENT}

If a market is not fully efficient (there are market imperfections), so that risk exposure is concave, risk 


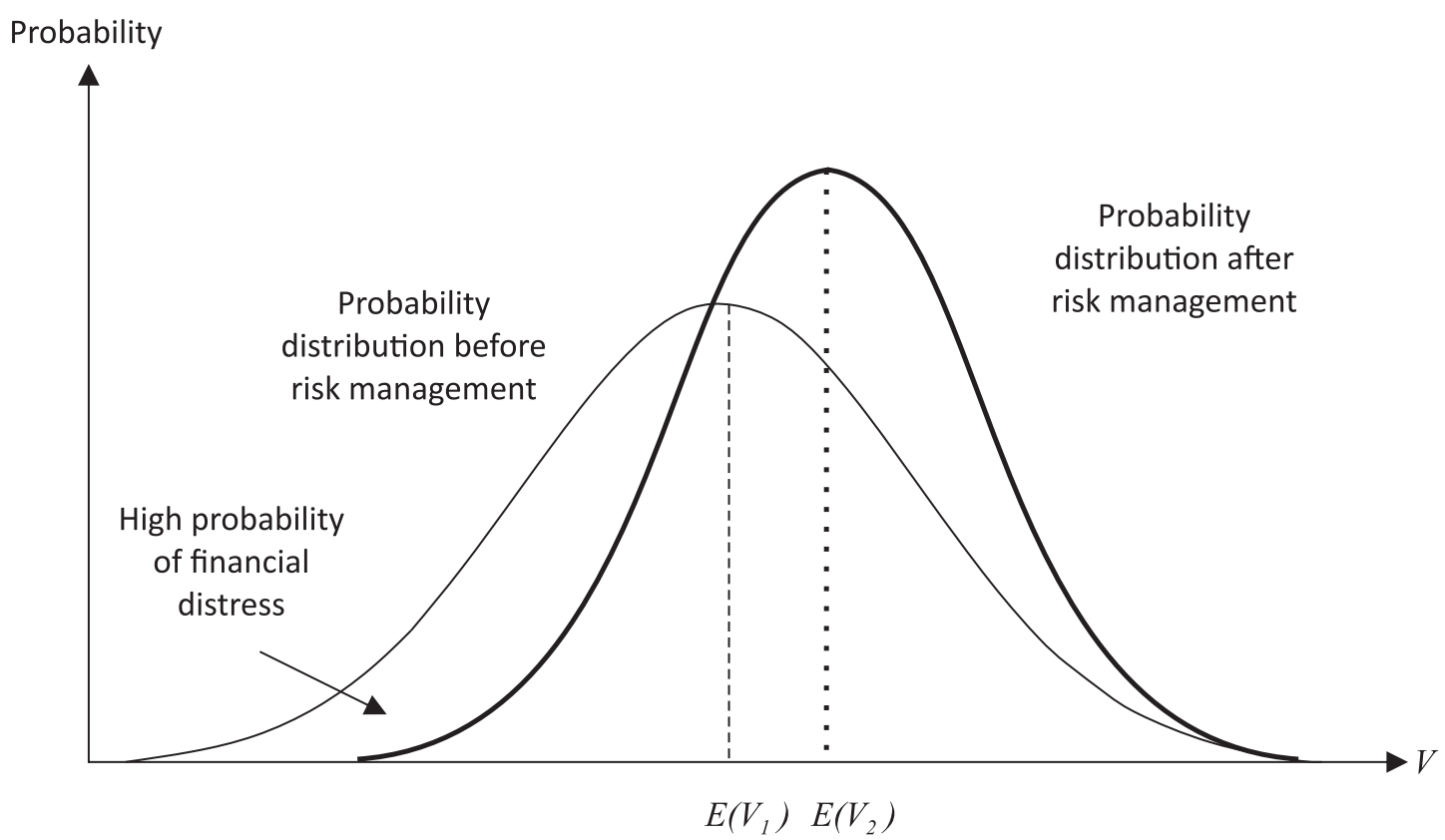

Figure 3 The influence of risk management on the expected firm value

Source: Adapted from Bartram (2000)

management can contribute to an increase in corporate value by reducing (Froot et al, 1994; Fatemi \& Luft, 2002; Graham \& Rogers, 2002):

- the cost of financial distress (including bankruptcy costs),

- agency costs and

- tax liabilities.

Strong and unpredictable changes in the value of a firm's cash flows caused by changes in market prices can cause financial distress, particularly in firms with a high financial leverage, low profitability and low liquidity. If the net cash flow of a firm decreases so much that the firm cannot timely and in full amount settle its obligations towards its creditors, a free transfer of assets from the owners to the creditors will occur on an efficient market. On an inefficient market, financial distress creates costs of a conflict between the owners and the creditors of the firm, customers' and suppliers' resentment towards cooperation with the firm, an increase in the cost of external funds (which increases opportunity costs due to the inability to finance investments), and the dissatisfaction of employees and managers (they lose motivation, demand higher salaries, leave the firm etc.) (Smith \& Stulz, 1985; Nance, Smith \& Smitson, 1993; Aretz, Bartram \& Dufey, 2007). If it causes bankruptcy, financial distress creates costs of bankruptcy proceedings and fees to third parties (lawyers, experts etc.).

Efficient risk management can either reduce or eliminate costs of financial distress and increase corporate value by reducing the variability of expected cash flows and the probability of a significant reduction in corporate value (Figure 3). If risk management eliminates a possibility of financial distress, then it will increase corporate value by the present value of expected costs of financial distress under the assumption that a corporation does not manage risk, calculated as the product of costs of financial distress and the probability that the corporation will encounter financial distress (Nance et al, 1993). By reducing the probability of encountering financial distress, risk management increases the debt capacity 
of the corporation, which enables it to borrow on more favorable terms and realize tax savings (interest expenses decrease taxable income) (Froot, Scharfstein \& Stein, 1993; Damodaran, 2008, 325-326). The increased debt capacity and a debt price reduction decrease the weighted average cost of capital (investment criteria), so that more investment alternatives can contribute to an increase in corporate value.

On an inefficient market, characterized by imperfect contracts and asymmetric information, agency costs mainly arise in connection with two problems:

- underinvestment and asset substitution, as an expression of a conflict between shareholders and creditors, and

- risk aversion on the managers' part and high management compensation, as an expression of a conflict between shareholders and managers.

The underinvestment problem occurs when shareholders give up on investments with a positive net present value if such investments primarily benefit bondholders (Myers, 1977). This problem is inherent to corporations with risky debt outstanding and a low value of total assets, whose shareholders are left with little or no free cash flow at all after the settlement of fixed liabilities towards creditors. Given the fact that the rearrangement of loans and a decrease in the financial leverage can be expensive (additional contractual clauses, a loss of tax savings etc.), risk management can be a less expensive solution to this problem. Risk management reduces the volatility of corporate value and the probability that it will fall below the level that will encourage shareholders to forgo investments with a positive net present value (Nance et al, 1993). It reduces the volatility of internal funds and the risk that they will not be sufficient to finance investments with a positive net present value. A lack of internal funds leads to an increase in an opportunity cost if the corporation decides to forgo investments, or an increase in the weighted average cost of capital if the corporation decides to use external (own and borrowed) funds (internal sources are less expensive than external sources of funding, especially when the corporation is exposed to high costs of financial distress and agency costs) (Froot et al, 1993).
Conflicts of interest between shareholders and creditors can also occur if shareholders give priority to very risky investments in comparison to less risky ones, even when their net present value is negative (asset substitution) (Myers, 1977). The shareholders' residual claim on the cash flows of the firm (shareholders are entitled to the cash flows of the firm when the firm settles its liabilities towards other stakeholders) has the characteristics of a call option on the firm assets, whose exercise price equals the value of the total debt. Since the value of an option increases with the riskiness of the underlying asset, shareholder value will increase if less risky investments are replaced with riskier ones. If shareholders are expected by creditors to behave in this manner, they may demand higher returns or stricter debt covenants, which increases agency costs and decreases corporate value. Risk management reduces the volatility of corporate value and the likelihood that shareholders will undertake risky investments (it is less likely that the value of debts will be greater than corporate value), so creditors will be willing to offer more favorable debt terms to the corporation. As there is no guarantee that the corporation that is currently managing risk will be doing so in the future, creditors may offer a lower interest rate only to those corporations that simultaneously arrange their debt and risk management programs (Aretz \& Bartram, 2010).

A conflict between managers and shareholders may occur if managers, in order to maximize their own welfare, undertake such activities that may not be in accordance with shareholders' interests, or with the aim of corporate value maximization. Such a conflict is pronounced when managers with high risk aversion have a high ownership stake, so that the occurrence of financial distress can cause them to lose everything - current and future benefits (salary, dividends and a capital gain), reputation and promotions (Meulbroek, 2002). To reduce their risk exposure and increase their well-being, managers can undertake activities with a negative net present value (for example, a conglomerate diversification and selection of a suboptimal capital structure), which cause a decrease in the welfare of shareholders. In order to align managers' interests with their own, shareholders will have to intensify monitoring over managers' activities and increase 
their salaries and bonuses, which causes the growth of agency costs and further reduce corporate value.

Risk management can reduce agency costs and increase corporate value if it reduces the riskiness of profitable investments, i.e. aligns preferences (risk aversion) and interests of managers and shareholders. Managers will then require lower compensation and be less inclined to undertake costly strategies to reduce risks which they are exposed to (Bartram, 2000). A reduced risk of investing in a corporation will also encourage shareholders to increase their ownership stakes (ownership concentration), which will increase the effectiveness of their monitoring over the activities carried out by managers. Shareholders will also require lower rates of return, which will directly reflect in an increased corporate value. Shareholders can adjust the degree of managers' aversion towards risk by using different managerial compensation schemes (Geczy, Minton \& Schrand, 1997; Coles, Daniel \& Naveen, 2006). Management ownership programs and tying managers' compensation to share prices result in a concave expected utility function of managers' welfare in comparison to the expected corporate value (the expression of managers' risk aversion), so that managers may be inclined to excessively reduce corporate risk exposure. Managers' compensation in the form of call options on shares of stock results in a convex expected utility function of managers' welfare (the expression of managers' risk seeking attitude), so that they may be inclined to increase corporate risk exposure in order to maximize the value of their call options and well-being.

When income tax is a convex function of taxable income (a tax liability grows faster than income, and decreases more slowly than income), then corporate value is a concave function of taxable income (corporate value grows more slowly than income, and decreases faster than income). In states characterized by very high income, the convexity in a tax liability can be caused by progressive statutory tax rates because a tax liability increases more than proportionally with the growth of income. In states characterized by losses or low income, convexity can be caused by time limits to carrying losses forward and using tax credits (for investment spending or income tax paid abroad). Thus, a corporation may be unable to fully use these tax benefits and decrease a tax liability in a short term (the present value of unused tax benefits decreases with the passage of time, as well as the effects of their use) (Geczy et al, 1997). When a tax liability is convex, a more volatile income stream leads to a higher average tax liability than it is the case with a less volatile income stream, given the fact that very high income increases a tax liability, and very low income limits the use of tax benefits. Risk management can limit income changes to a specific optimal range without extreme values, and reduce a tax liability (Froot et al, 1993; Graham \& Rogers, 2002). If a firm smooths its taxable income, savings due to less tax paid in periods of high income will be greater than losses due to more tax paid in periods of lower income. Risk management can also reduce a tax liability by increasing the debt capacity, which is explained as the effect of reducing the costs of financial distress.

\section{OPTIMAL RISK EXPOSURE}

If the corporate value function is concave, investors may expect managers to completely eliminate or minimize risk exposure, which is in line with the view that they are very risk averse (aversion tends to infinity). However, given the very high cost of such an approach, it is more likely that investors will expect managers to reduce the overall risk exposure to an optimal level (it can be zero exposure), which allows the maximizing of corporate value. The optimal or acceptable risk exposure is often determined by using the desired corporate bond rating, which reflects the probability that a corporation will encounter financial distress (Nocco \& Stulz, 2006). If the management expects that a decline in the bond rating will cause a significant increase in the cost of the debt and a decrease in corporate value, they may decide to increase risk management efforts in order to reduce the likelihood of such an outcome. In other words, the management can determine the size of the investment in risk management, so as to reach a certain credit rating of bonds, and maximize corporate value. The size of an investment increases if a corporation has more development opportunities, which it will not be able to realize if the cost of the debt increases. A mature corporation with fewer development 
opportunities will invest less in risk management, because such a corporation can create greater shareholder value by increasing the leverage and using tax savings. Since the share of equity in the capital structure also significantly determines the bond rating, the management can reduce investment in risk management if they increase the share of equity (the share of equity and risk management are substitutes). Such a decision is financially justified if the cost of risk management decreases in an amount bigger than an increase in the cost of capital (equity is more expensive than a debt).

To determine the optimal amount of corporate risk exposure, H. Shin and R. M. Stulz (2000) take into consideration the cost of bearing unhedged risk $\left(C_{n h r}\right)$ and the cost of hedging $\left(C_{h}\right)$. Unhedged risk is the risk that remains after hedging, i.e. risk management. The cost $C_{h}$ arises in connection with the use of financial derivatives (forwards, futures, options etc.), whose transaction costs are relatively low. Given the fact that some risks are more difficult to eliminate, after a certain level, a further incremental reduction in unhedged risk becomes very expensive. The total cost of bearing unhedged risk $\left(T C_{n h r}\right)$ is equal to the sum of $C_{n h r}$ AND $C_{h}$. H. Shin and R. M. Stulz conclude that the optimal amount of unhedged risk is reached when a firm minimizes $T C_{n h r}$, i.e. when it equalizes the marginal cost of bearing unhedged risk $\left(M C_{n h r}\right)$ and the marginal cost of hedging $\left(M C_{h}\right)$. It should be noted that $M C_{n h r}$ is the increasing, and $M C_{h}$ the decreasing function of unhedged risk (Figure 4). H. Shin and R. M. Stulz further analyze the value of firms with the same $M C_{h}$ functions, but different $M C_{n h r}$ functions. They conclude that a firm with a higher $M C_{n h r}$ has a lower level of unhedged risk and a lower value due to a higher $T C_{n h r}$, which means that it is possible for a firm with more unhedged risk to be capable of having a higher value. If the impact of an exogenous factor causes an increase in unhedged risk, the $M C_{h}$ function will move to the right (the cost of marginal risk reduction remains unchanged), whereas the $M C_{n h r}$ function remains unchanged. Then, $T C_{n h r}$ will rise causing a reduction in firm value and an increase in the optimal amount of unhedged risk.
In accordance with the analysis conducted by $\mathrm{H}$. Shin and R. M. Stulz, it can be concluded that risk management at the corporate level makes sense as long as it causes benefits (a decrease in costs of market imperfections) bigger than costs. As a typical explicit cost of risk management, A. Damodaran (2008, 320-321) considers the insurance premium, which firms pay in order to ensure themselves against various risks. This cost is higher if insurance provides more complete risk coverage and if the probability of the occurrence and the expected impact of risk is higher. Firms that use financial options pay the explicit cost of premium (the option price). Companies do not pay the explicit cost, but rather face a possible implicit cost of using financial forwards and futures. If a firm buys futures to protect itself against a decrease in prices of its products, it will have to give up higher income (the implicit cost) if the price rises. The financial literature points out that costs of risk management are diverse, but relatively low, even on very inefficient markets (Bartram, 2000; Stephens 2001, 27). It is, therefore, unlikely that costs will exceed benefits of risk management at high levels of risk, which would be a sufficient reason for a firm to accept the total risk. J. J. Stephens $(2001,27)$ warns that the acceptance of the total or a high level of risk is a speculative strategy, which requires a careful

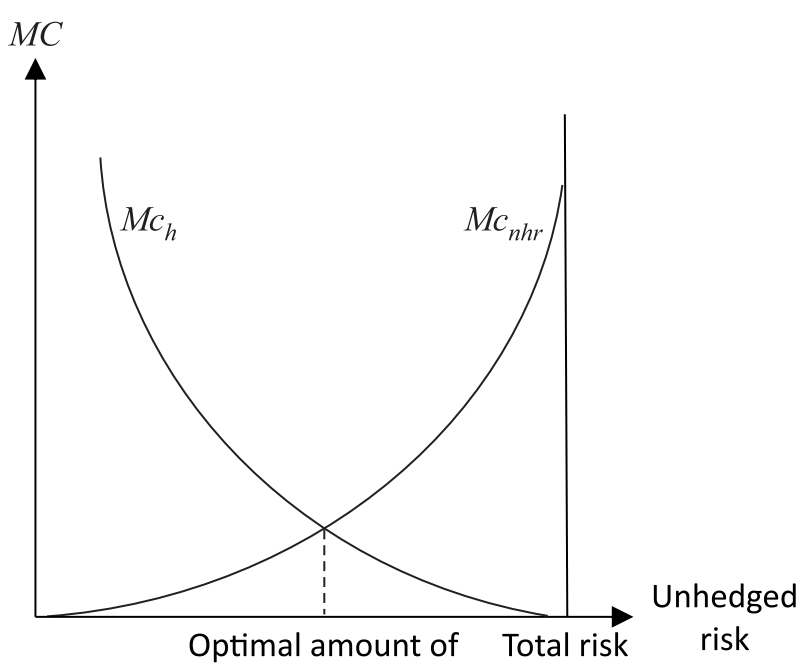

Figure 4 The optimal amount of unhedged risk

Source: Shin \& Stulz, 2000 
evaluation of information and forecasts before its adoption, as well as constant monitoring after such adoption, so that a corrective action could be taken in the event that the situation does not develop as expected.

R. M. Stulz (1996) introduced the comparative advantage of a firm in bearing certain financial risks in order to explain reasons for selective risk management. A firm has a comparative advantage if, in relation to investors and other firms, it has better access to market information important for predicting changes in certain market prices. Thus, if a firm has a comparative advantage in bearing foreign currency risk, the management can increase the exposure of the firm to such a risk because they can promptly and effectively respond to adverse changes (for example, by using currency forwards) and take advantage of favorable (by taking an unhedged position) changes in exchange rates. Simultaneously, it will increase investments in the management of other risks to reduce the likelihood of their adverse impact on firm value. The management should carefully evaluate the comparative advantage of the firm in order to reduce the probability of losses resulting from selective risk management. If a firm has a large market share and a high turnover on the foreign exchange market, the likelihood that the firm will have a comparative advantage on that market increases, and the probability of losses decreases. It should be noted that the comparative advantage of the firm provides flexibility to the management decisionmaking process (real options), so that exposure to a certain risk becomes convex.

\section{CONCLUSION}

Starting from the basic theoretical assumptions about market efficiency and investors' risk aversion, the paper has analyzed the theoretical arguments on the impact of risk management on corporate value. If it is assumed that a market is perfectly efficient and investors fully rational, then risk management at the corporate level is not financially justified because investors can effectively eliminate the risk of their investment by using diversification. However, if one takes into account market imperfections and choices that investors really make in situations of uncertainty, then conclusions about risk management change. Market imperfections, such as the cost of financial distress, agency costs and taxation can cause the development of concave risk exposure. In view of Jensen's inequality, risk management will cause a reduction in the cost of market imperfections and help increase corporate value when risk exposure is concave. If investors' risk aversion is pronounced, risk management at the corporate level may be effective even when risk exposure is linear. Therefore, the conclusion is that the first hypothesis set out in this paper should not be rejected.

The financial literature often analyzes the problem of determining the optimal amount of corporate risk exposure. A solution to this problem is mainly determined by investors' risk aversion, the cost of risk management and the competitive advantage of a corporation on the relevant market. While it is possible that a corporation will completely eliminate the exposure of some items to a certain risk, it will probably not completely eliminate the exposure of all items to the same risk. A corporation will seek to reduce exposure to a particular risk to a level where the total cost of risk management is minimal, i.e. the level at which the marginal cost of bearing unhedged risk equals the marginal cost of risk management. Given the fact that costs of risk management are relatively low and potential benefits of risk management are high, it is unlikely that a corporation will make a decision not to manage the risk at all, i.e. to accept the total risk of changes in a certain market price. Finally, a corporation will make a decision to accept a higher level of certain risk if it has a comparative advantage in bearing of this risk, although it should be noted that, then, the exposure of the corporation becomes convex. The paper lists the arguments supporting the view that the management can maximize corporate value if they optimize corporate risk exposure, so the second hypothesis set out in this paper should not be rejected, either.

There are two contributions of this paper. First, the conducted theoretical research contributes to the further development of theoretical and empirical models for the impact of risk exposure on financial effects of risk management at the corporate level (Smith 
\& Stulz, 1985; MacKay \& Moeller, 2007). The paper has developed a general approach to evaluating effects of risk management, which takes into account the level, shape and direction of the relationship between the value (of a firm, assets, liabilities etc.) and various risk factors, as well as the level of investors' risk aversion. Second, by including the cost of risk management and the cost of unhedged risk in the analysis of financial effects of risk management, this paper contributes to the further development of theoretical views on the optimal level of risk exposure. By emphasizing the comparative advantage of a corporation on a relevant market, the analysis has indirectly taken into consideration real options as the representation of operational risk management strategies. The theoretical approach developed in this paper represents a solid basis for a future theoretical and empirical research, but has a limited practical value because it does not explain the specific models for the evaluation of financial effects of risk management. However, this approach can serve as the basis for the development of guidelines and models that will help managers make informed decisions in a real business environment.

Theoretical research commonly assumes that corporations manage risk by using financial derivatives, while neglecting the importance of operational risk management strategies. This problem has only been implied in this paper by emphasizing the fact that a firm's exposure to risk may become convex if the management increases the level of the business flexibility of the firm through the development of real options. A firm with real options can mitigate the impact of adverse changes and take advantage of favorable changes in market prices in order to maximize value. Therefore, future research should focus on an analysis of the impact of operational risk management strategies on corporate value. Empirical research on the impact of financial risk management strategies on corporate value in developed countries does not always provide support to theoretical conclusions (Graham \& Rogers, 2002; Aretz et al, 2007). The reasons for such empirical findings should partially be sought in inadequately developed empirical models which only analyze one aspect of risk management (i.e. only the cost of financial distress).
Therefore, future empirical research, especially in economies with underdeveloped markets, should recognize the complexity of risk exposure and risk management in order to allow a reliable assessment of theoretical conclusions.

\section{REFERENCES}

Adler, M., \& Dumas, B. (1984). Exposure to currency risk: definition and measurement. Financial Management, 13(2), 41-50. doi: $10.2307 / 3665446$

Aretz, K., \& Bartram, S. M. (2010). Corporate hedging and shareholder value. Journal of Financial Research, 33(4), 317-371. doi: 10.1111/j.1475-6803.2010.01278.x

Aretz, K., Bartram, S. M., \& Dufey, G. (2007). Why hedge? Rationales for corporate hedging and value implications. Journal of Risk Finance, 8(5), 434-449. doi: $10.1108 / 15265940710834735$

Bartram, S. M., (2000). Corporate Risk Management as a Lever for shareholder value creation. Financial Markets, Institutions and Instruments, 9(5), 279-324. doi: 10.1111/1468-0416.00038

Bartram, S. M. (2004). Linear and nonlinear foreign exchange rate exposures of German nonfinancial corporations. Journal of International Money and Finance, 23(4), 673-699. doi: 10.1016/j. jimonfin.2004.03.002

Berle, A. A., \& Means, G. C. (1932). The Modern Corporation and Private Property. New York, NY: Macmillan.

Bodnar, G. M., \& Gebhardt, G. (1999). Derivatives usage in risk management by U.S. and German non-financial firms: A comparative survey. Journal of International Financial Management and Accounting, 30(3), 153-187. doi: 10.1111/1467646X.00049

Brown, G. W., Crabb, P. R., \& Haushalter, D. (2006). Are firms successful at selective hedging? Journal of Business, 79(6), 2925-2949. doi: 10.1086/508004

Coles, J. L., Daniel, N. D., \& Naveen, L. (2006). Managerial incentives and risk-taking. Journal of Financial Economics, 79(2), 431-468. doi: 10.1016/j.jfineco.2004.09.004

Damodaran, A. (2008). Strategic Risk Taking: A Framework for Risk Management. Upper Saddle River. NJ: Pearson Education.

Dumas, B. (1978). The theory of trading firm revisited. Journal of Finance, 33(3), 1019-1030. doi: 10.1111/j.1540-6261.1978. tb02041.x 
Fatemi, A., \& Luft, C. (2002). Corporate risk management: costs and benefits. Global Finance Journal, 13(1), 29-38. doi: 10.1016/ S1044-0283(02)00037-6

Friberg, R. (1999). Exchange Rates and the Firm: Strategies to Manage Exposure and the Impact of EMU. New York, NY: Palgrave Macmillan.

Froot, K. A., Scharfstein, D. S., \& Stein, J. C. (1993). Risk management: coordinating corporate investment and financing policies. Journal of Finance, 48(5), 1629-1658. doi: 10.1111/j.1540-6261.1993.tb05123.x

Froot, K. A., Scharfstein, D. S., \& Stein, J. C. (1994). A framework for risk management. Harvard Business Review, 72(6), 91-102. doi: 10.1111/j.1745-6622.1994.tb00415.x

Geczy, C., Minton, B. A., \& Schrand, C. (1997). Why firms use currency derivatives. Journal of Finance, 52(4), 1323-1354. doi: 10.1111/j.1540-6261.1997.tb01112.x

Graham, J. R., \& Rogers, D. A. (2002). Do firms hedge in response to tax incentives? Journal of Finance, 57(2), 815-839. doi: 10.1111/1540-6261.00443

Jaksic, M. (2012). Risk management of portfolio securities. Economic Horizons, 14(3), 155-168. doi:10.5937/ekonhor1203151J

Joseph, N. L. (2000). The choice of hedging techniques and the characteristics of UK industrial firms. Journal of Multinational Financial Management, 10(2), 161-184. doi: 10.1016/S1042$444 X(99) 00025-0$

Kahneman, D., \& Tversky, A. (1979). Prospect theory: an analysis of decision under risk. Econometrica, 47(2), 263-292. doi: $10.2307 / 1914185$

Mackay, P., \& Moeller, S. B. (2007). The value of corporate risk management. Journal of Finance, 62(3), 1379-1419. doi: 10.1111/j.1540-6261.2007.01239.x

Meulbroek, L. K. (2002). A senior manager's guide to integrated risk management. Journal of Applied Corporate Finance, 14(4), 56-70. doi: 10.1111/j.1745-6622.2002.tb00449.x

Modigliani, F., \& Miller, M. H. (1958). The cost of capital, corporation finance and the theory of investment. American Economic Review, 48(3), 261-297.

Modigliani, F., \& Miller, M. H. (1963). Corporate income taxes and the cost of capital: a correction. American Economic Review, 53(3), 433-443.

Myers, S. C. (1974). Interactions of corporate financing and investment decisions - Implications for capital budgeting.
Journal of Finance, 29(1), 1-25. doi: 10.1111/j.1540-6261.1974. tb00021.x

Myers, S. C. (1977). Determinants of corporate borrowing. Journal of Financial Economics, 5(2), 147-175. doi: 10.1016/0304405X(77)90015-0

Myers, S. C., \& Majluf, N. (1984). Corporate financing and investment decisions when firms have information investors do not have. Journal of Financial Economics, 13(2), 187-221. doi: 10.1016/0304-405X(84)90023-0

Nance, D. R., Smith, C. W., \& Smitson, C. W. (1993). On the determinants of corporate hedging. Journal of Finance, 48(1), 267-284. http://doi.org/10.2307/2328889

New York Stock Exchange. (2013). NYSE Listed Company Manual: Corporate Governance Standards s303.A.07(D). New York, US.

Nocco, B. W., \& Stulz, R. M. (2006). Enterprise risk management: theory and practice. Journal of Applied Corporate Finance, 18(4), 8-20. doi: 10.1111/j.1745-6622.2006.00106.x

Organization for Economic Cooperation and Development. (2015). G20/OECD Principles of Corporate Governance. Paris, France.

Sarbanes-Oxley Act of 2002, Pub. L. 107-204, 116 Stat. 745 (codified as amended at 15 U.S.C. $\S \S 7201-7266$ ).

Sharpe, W. (1964). Capital asset prices: A theory of market equilibrium under conditions of risk. Journal of Finance, 19(3), 425-442. doi: 10.1111/j.1540-6261.1964.tb02865.x

Shin, H., \& Stulz, R. M. (2000). Firm value, risk, and growth opportunities. Working Paper No. 7808. Retreived from National Bureau of Economic Research, website: http:// www.nber.org/papers/w7808.

Smith, C. W., \& Stulz, R. M. (1985). The Determinants of Firms' Hedging Policies. Journal of Financial and Quantitative Analysis, 20(4), 391-405. doi: 10.2307/2330757

Stephens, J. J. (2001). Managing Currency Risk Using Financial Derivatives. Chichester, England: John Wiley and Sons.

Stulz, R. M. (1996). Rethinking risk management. Journal of Applied Corporate Finance, 9(3), 8-24. doi: 10.1111/j.17456622.1996.tb00295.x

Tversky, A., \& Kahneman, D. (1992). Advances in prospect theory: Cumulative representation of uncertainty. Journal of Risk and uncertainty, 5(4), 297-323. doi: 10.1007/BF00122574 
Received on November $13^{\text {th }} 2015$,

after revision, accepted for publication on $15^{\text {th }}$ December 2015.

Published online on $25^{\text {th }}$ December 2015.

Milan Cupic is an Assistant Professor at the Faculty of Economics of the University of Kragujevac the Republic of Serbia. At the same Faculty, he defended his doctoral thesis in the field of International Business Finance. He teaches Business Finance and Financial Restructuring of Companies. His research interests include foreign exchange risk management, cost-benefit analysis, performance measurement, and corporate governance. 


\title{
UPRAVLJANJE RIZIKOM I VREDNOST KORPORACIJE
}

\author{
Milan Čupić* \\ Ekonomski fakultet Univerziteta u Kragujevcu
}

\begin{abstract}
U radu je predstavljen teorijski okvir za analizu uticaja upravljanja rizikom na vrednost korporacije. Kao relevantni činioci koji određuju ovaj uticaj, u radu su analizirane tržišne nesavršenosti i averzija investitora prema riziku. Rezultati sprovedenog istraživanja ukazuju na to da upravljanje rizikom doprinosi povećanju vrednosti korporacije ako je, pod uticajem tržišnih nesavršenosti, njena izloženost riziku konkavna. Kao izraz tržišnih nesavršenosti, u radu su analizirani troškovi finansijskih teškoća, agencijski troškovi i oporezivanje. Rezultati sprovedenog istraživanja, takođe, ukazuju na to da politika upravljanja rizikom za cilj ne treba da ima minimiziranje, već optimiziranje izloženosti riziku, uz uvažavanje troškova upravljanja rizikom, averzije investitora prema riziku i komparativne prednosti korporacije na relevantnom tržištu.
\end{abstract}

Ključne reči: upravljanje rizikom, vrednost korporacije, izloženost riziku, tržišne nesavršenosti, averzija prema riziku

\section{JEL Classification: $\mathrm{G} 14, \mathrm{C} 32$}

\section{UVOD}

Finansijski rizik može biti definisan kao promenljivost ili neizvesnost budućih novčanih tokova preduzeća, ili kao verovatnoća nastupanja nekog neželjenog ishoda. Može biti izazvan različitim činiocima, mada se u finansijama najčešće analizira uticaj neočekivanih promena tržišnih cena (devizni kursevi, kamatne stope, cene roba i slično) na novčane tokove preduzeća. Upravljanje rizikom podrazumeva procenu rizika koji utiču na novčane tokove preduzeća i primenu odgovarajućih strategija za kontrolu tih rizika. Cilj upravljanja rizikom, u zavisnosti od stepena averzije

\footnotetext{
* Korespondencija: M. Čupić, Ekonomski fakultet Univerziteta u Kragujevcu, Đ. Pucara 3, 34000 Kragujevac, Republika Srbija; e-mail: mcupic@kg.ac.rs
}

investitora i menadžera prema riziku, može biti definisan kao održavanje promena novčanih tokova $\mathrm{u}$ određenom rasponu ili minimiziranje tih promena. Strategije upravljanja rizikom mogu biti finansijske, ako podrazumevaju primenu finansijskih derivata (forvardi, fjučersi, opcije i slično), ili poslovne, ako podrazumevaju razvoj poslovne fleksibilnosti i diverzifikaciju poslovanja. Upravljanje rizikom je finansijski opravdano ako doprinosi povećanju vrednosti preduzeća, utvrđene diskontovanjem očekivanog slobodnog novčanog toka preduzeća.

Empirijska istraživanja otkrivaju da preduzeća uglavnom upravljaju rizicima, pri čemu najviše napora ulažu u upravljanje deviznim i kamatnim rizicima (Bodnar \& Gebhardt, 1999; Brown, Crabb \& Haushalter, 2006; Aretz \& Bartram, 2010). Preduzeća obično upravljaju rizicima tekućih transakcija, kada koriste 
finansijske derivate, dok manje pažnje posvećuju rizicima budućih transakcija, pa retko koriste poslovne strategije upravljanja rizikom (Stulz, 1996; Joseph, 2000). Pri tome, treba imati u vidu da upravljanje rizikom često nije pitanje izbora ili strateškog opredeljenja preduzeća, već predstavlja odgovor na zahteve utvrđene smernicama međunarodnih organizacija (na primer, Organization for Economic Cooperation and Development, 2015) i tržišta kapitala (na primer, New York Stock Exchange, 2013), kao i zakonskim propisima (na primer, Sarbanes-Oxley Act of 2002). Ovi zahtevi su odraz napora da se zaštite interesi investitora, pri čemu se $u$ obzir ne uzima finansijska opravdanost upravljanja rizikom za preduzeće. Prema tome, iako bi empirijski podaci o rasprostranjenosti upravljanja rizikom mogli da budu protumačeni kao odraz uverenja da upravljanje rizikom doprinosi povećanju vrednosti preduzeća, moguće je da preduzeća rizikom upravljaju iz drugih razloga.

Predmet teorijskog istraživanja $u$ ovom radu je uticaj upravljanja rizikom na vrednost korporacije (akcionarskog preduzeća). Polazeći od prethodnih istraživanja (Smith \& Stulz, 1985; Fatemi \& Luft, 2002; Meulbroek, 2002), kao relevantni činioci koji određuju ovaj uticaj, analizirane su tržišne nesavršenosti i averzija investitora prema riziku. U radu je posebno razmotren problem definisanja optimalnog (prihvatljivog) nivoa izloženosti riziku, koji je bio predmet više teorijskih i empirijskih istraživanja (Shin \& Stulz, 2000; Nocco \& Stulz, 2006).

Cilj rada je da se, pregledom i analizom zaključaka prethodnih teorijskih istraživanja, ukaže na složenost problema ocene finansijske opravdanosti odluke o upravljanju rizikom na nivou korporacije i stvori osnova za razvoj smernica koje će menadžerima pomoći da donesu adekvatne odluke $u$ vezi sa upravljanjem rizikom.

Polazeći od zaključaka prethodnih teorijskih istraživanja, utvrđene su sledeće dve istraživačke hipoteze:

H1: Upravljanje rizikom može doprineti povećanju vrednosti korporacije samo ako je vrednost korporacije konkavna funkcija tržišnih cena.

H2: Upravljanje rizikom može doprineti maksimiranju vrednosti korporacije ako omogući održavanje izloženosti riziku na optimalnom nivou, pri kojem su koristi veće od troškova upravljanja rizikom.

Istraživanje će biti sprovedeno kvalitativnom analizom rezultata prethodnih teorijskih istraživanja, što će omogućiti izvođenje zaključaka kroz teorijsko uopštavanje.

Rad je strukturiran na sledeći način. U prvom delu rada ce biti predstavljena evolucija teorijskih stavova o finansijskoj opravdanosti upravljanja rizikom na nivou korporacije. U drugom delu rada će biti analiziran uticaj oblika veze vrednosti korporacije i tržišnih cena na isplativost upravljanja rizikom, a u trećem, očekivani efekti (koristi) upravljanja rizikom. U četvrtom delu rada će biti razmotren problem definisanja optimalnog nivoa izloženosti riziku, dok će u petom delu biti predstavljeni zaključci i smernice za buduća istraživanja.

\section{EVOLUCIJA TEORIJSKIH STAVOVA O UPRAVLJANJU RIZIKOM}

U finansijskoj teoriji je od početka XX-og veka do 1970-ih bio dominantan stav da korporacije ne treba da upravljaju rizicima svog poslovanja, budući da imaju veliki broj vlasnika, koji poseduju mali deo ukupnog vlasništva i snose mali deo ukupnog rizika korporacije. Ako diverzifikuju svoj portfolio ulaganja, tj. ako raspoloživa finansijska sredstva plasiraju u nekoliko alternativa ulaganja sa negativnom korelacijom očekivanih novčanih tokova (prinosa), investitori mogu upravljati rizikom uspešnije od korporacije. A. A. Berle i G. C. Means (1932, 340344) su smatrali da je upravljanje rizikom finansijski opravdano samo $\mathrm{u}$ privatnim preduzećima jednog vlasnika (preduzetnika) koji ulaže sopstveni kapital i ima pravo na neto dobitak, kao nadoknadu za upravljanje i preuzimanje rizika. Stav ovih autora je bio da su korporacije nastale kako bi preduzetnici (vlasnici privatnih preduzeća) preneli rizike poslovanja na veliki broj malih investitora, pa korporacije ne treba da upravljaju rizikom, već to treba da urade sami investitori, u skladu sa svojim preferencijama. Investitori dobijaju odgovarajuću nadoknadu za rizik 
koji preuzimaju kako bi bili spremni da korporaciji ustupe svoj kapital, što je analogno zaradama koje zaposleni dobijaju kako bi bili spremni da preduzeću ustupe svoj rad.

Objašnjenu logiku su teorijski uobličili F. Modigliani i M. H. Miller (1958), teoremom, kojom su postavili osnove savremenih poslovnih finansija. Polazeći od pretpostavke o odsustvu tržišnih nesavršenosti, oni su utvrdili da se vrednost stvara ulaganjima sa pozitivnim poslovnim novčanim tokom, pri čemu je irelevantno kako će ta ulaganja biti finansirana - iz pozajmljenog ili sopstvenog kapitala. Drugim rečima, finansijske odluke, uključujući one iz domena upravljanja rizikom, ne doprinose stvaranju vrednosti korporacije, već samo određuju način njene raspodele između investitora (vlasnika i kreditora). Njihov stav je bio da korporacije ne treba da upravljaju rizikom, ni zato što racionalni investitori na efikasnom tržištu to mogu uspešnije sami da urade. Sličnog stava je bio W. Sharpe (1964), koji je razvio CAPM (Capital Asset Pricing Model) sna pretpostavci da korporacije ne treba da upravljaju rizicima svog poslovanja (nesistematskim rizicima), već investitori sami treba diverzifikacijom da svedu rizik svog portfolija ulaganja na željeni nivo. Korporacije treba da donose odluke imajući u vidu samo sistematski (tržišni) rizik, tj. rizik na koji ne mogu uticati (ne mogu ga smanjiti instrumentima upravljanja rizikom) i koji jedino određuje premiju za rizik ulaganja u korporaciju. Sličnog stava su bili drugi autori koji su, polazeći od portfolio teorije $\mathrm{H}$. Markowitz-a, nezavisno razvili svoje verzije CAPM modela (J. Treynor, J. Lintner, J. Mossin, F. Black).

Teorije koje zagovaraju stav da korporacije ne treba da upravljaju rizikom, polaze od pretpostavke da je tržište efikasno, a investitori racionalni. Kada se u analizu uvedu faktori svojstveni stvarnom poslovnom okruženju, tj. tržišne nesavršenosti (na primer, oporezivanje, finansijske teškoće, agencijski troškovi) i stvarni investitori, takav stav je teško opravdati. F. Modigliani i M. H. Miller (1963) su, po objavljivanju svoje teoreme, priznali da, ukoliko se $u$ analizu uvede samo jedna tržišna nesavršenost - porez na dobitak korporacije, struktura kapitala više nije irelevantna, a time ni upravljanje rizikom. S. C. Myers (1974), i S. C. Myers i N. Majluf (1984) ističu da se korporacije sa visokim iznosom rizičnih dugova, kod kojih raste verovatnoća nastupanja finansijskih teškoća (debt overhang), mogu suočiti sa problemom pribavljanja dodatnog kapitala za finansiranje novih ulaganja, naročito u uslovima visoke neizvesnosti. Upravljanje rizikom, tada, može doprineti povećanju vrednosti korporacije, ako smanji promenljivost novčanih tokova i verovatnoću nastupanja finansijskih teškoća, jer će korporacija moći da pribavi eksterne izvore finansiranja pod povoljnijim uslovima i da preduzme veću vrednost ukupnih ulaganja.

Pretpostavka o racionalnim investitorima je razvijena u okviru Teorije očekivane korisnosti, koja objašnjava proces odlučivanja pojedinaca u uslovima rizika i neizvesnosti i predstavlja polaznu osnovu za veliki broj značajnih finansijskih teorija (na primer, portfolio teorija H. Markowic-a, CAPM model). Ova teorija je normativna, jer propisuje pravila koja svaki racionalni i potpuno informisani pojedinac treba da sledi kada donosi odluku. Pretpostavlja se da pojedinci imaju uniformno konkavnu funkciju korisnosti (izraz averzije prema riziku), koja izražava njihove preferencije, i da uvek biraju alternativu (na primer, ulaganja) koja ima najveću očekivanu korisnost (Jaksic, 2012). Teorija očekivane korisnosti je vremenom postala predmet kritika, među kojima je najpoznatija predstavljena Teorijom izgleda (prospect theory) (Kahneman \& Tversky, 1979; Tversky \& Kahneman, 1992). Ova teorija je deskriptivna, jer opisuje kako stvarni pojedinci u stvarnom poslovnom okruženju donose odluke, koristeći dostupne informacije. Pošto su pošli od pretpostavke da pojedinci pažnju usmeravaju na moguće promene bogatstva (ishod odluke), a ne na ukupno bogatstvo, D. Kahneman i A. Tversky su funkciju korisnosti ukupnog bogatstva pojedinca zamenili funkcijom vrednosti mogućih ishoda u odnosu na referentnu tačku (status quo).

D. Kahneman i A. Tversky su dokazali da pojedinci asimetrično reaguju na dobitke i gubitke - njihova averzija prema riziku je veća u odnosu na dobitke, nego u odnosu na gubitke. Ako treba da biraju između verovatnog i sigurnog dobitka, većina pojedinaca bira sigurni dobitak, čak i kada je očekivana vrednost ove alternative manja. Ovakav izbor je u skladu sa Teorijom očekivane korisnosti, jer izražava konkavnu funkciju korisnosti (vrednosti) pojedinca, tj. averziju prema riziku (Slika 1). Kada treba da biraju između 
verovatnog i sigurnog gubitka, većina pojedinaca prednost daje verovatnom gubitku, čak i kada je očekivana vrednost ove alternative manja. To znači da su pojedinci skloni riziku kada su u pitanju gubici, tj. njihova funkcija korisnosti (vrednosti) je konveksna u odnosu na gubitke (Slika 1). D. Kahneman i A. Tversky su, takođe, uočili da je funkcija korisnosti (vrednosti) pojedinaca strmija za gubitke, nego za dobitke (pojedinci su osetljiviji na gubitke, nego na dobitke), što su označili izrazom averzije investitora prema gubicima (Slika 1). Ako se ovi nalazi primene na korporaciju, može se očekivati da će tražnja za akcijama korporacije koja nudi sigurniji prinos biti veća od tražnje za akcijama korporacije koja nudi manje siguran prinos, čak i kada je očekivani prinos drugog ulaganja veći (Stephens, 2001, 38-39).

Pod uticajem izmenjenih teorijskih stavova $u$ vezi sa ulogom finansijske politike $u$ procesu stvaranja vrednosti i odnosa investitora prema riziku, razvijena je savremena paradigma finansijskog upravljanja. U njenoj osnovi se nalazi osnovna tvrdnja F. Modigliani-a i M. H. Miller-a da korporacije stvaraju vrednost ulaganjima sa pozitivnom neto sadašnjom vrednošću očekivanog novčanog toka iz poslovanja. Ova tvrdnja je dopunjena stavom da je finansijska politika kritični faktor koji posredno doprinosi povećanju vrednosti

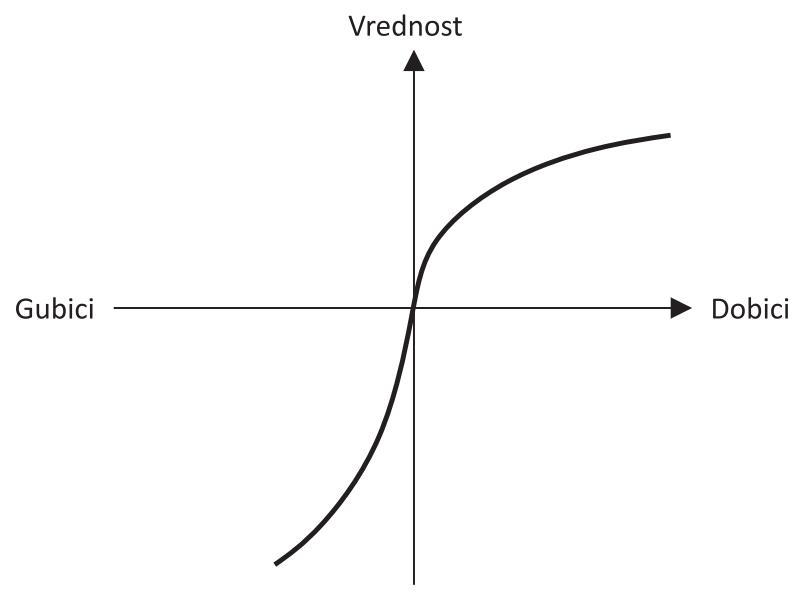

Slika 1 Funkcija vrednosti prema Teoriji izgleda

Izvor: Kahneman \& Tversky, 1979 korporacije, jer joj omogućava da preduzima ulaganja koja stvaraju vrednost, tako što obezbeđuje pristup povoljnijim izvorima finansiranja. Uloga politike upravljanja rizikom, kao segmenta finansijske politike korporacije, je da prati i kontroliše uticaj promena tržišnih cena (kamatne stope, devizni kursevi itd.) i drugih faktora na novčane tokove korporacije i obezbedi stabilno finansiranje ulaganja sa pozitivnom neto sadašnjom vrednošću (Froot, Scharfstein \& Stein, 1994). Upravljanje rizikom na nivou korporacije je još značajnije ako se ima $u$ vidu da pojedinci ne mogu da budu jednako uspešni u upravljanju rizikom kao korporacije, jer poseduju manje informacija (informaciona asimetrija), moraju da plate relativno više troškove hedžinga, i ne mogu da smanje rizik i troškove stečaja (finansijskih teškoća).

\section{IZLOŽENOST RIZIKU I UPRAVLJANJE RIZIKOM}

B. Dumas (1978) smatra da izloženost riziku treba definisati kao ono „što neko ima pod uticajem rizika“. Preciznije se izloženost riziku može definisati kao osetlijvost vrednosti (knjigovodstvene, tržišne i slično) preduzeća ili određenih pozicija (imovine, obaveza, prihoda, troškova, novčanih tokova i slično) na slučajne promene neke tržišne cene (cena robe, devizni kurs, kamatna stopa i slično) u određenom trenutku u budućnosti. To znači da je izloženost riziku moguće iskazati na sledeći način (Adler \& Dumas, 1984):

$V_{p}=E\left(\partial V / \partial p_{i}\right)$

Formula (1) definiše izloženost riziku $\left(V_{p}\right)$ kao tekuće očekivanje $(E)$ u pogledu parcijalne osetljivosti vrednosti preduzeća ili pozicije $(V)$ u odnosu na buduće vrednosti $i$-te cene $\left(p_{i}\right)$ ( $V$ je izloženo uticaju većeg broja cena). Izloženost $V_{p}$ može biti shvaćena kao nagib krive koja izražava odnos $V$ i $p_{i}$ (što je izloženost veća, nagib krive je veći). Pozitivna (negativna) vrednost $V_{p}$ ukazuje na to da se $V$ povećava sa povećanjem (smanjenjem) $p_{i}$. Budući da izloženost riziku može biti nelinearna (konveksna ili konkavna), parcijalni izvod drugog reda funkcije $V$ omogućava ocenu oblika veze između $V$ i $p_{i}$ : 
$V_{p p}=E\left(\partial^{2} V / \partial p_{i}^{2}\right)$

Pozitivna (negativna) vrednost $V_{p p}$ ukazuje na to da je $V_{p}$ konveksna (konkavna) funkcija $p_{i}$. Kada je $V_{p p}=0$, tada je veza između $V$ i $p_{i}$ linearna. Kvadratna, kubna i funkcija hiperboličnog sinusa su česti oblici konkavne, a funkcije kubnog korena i inverzni hiperbolični sinus konveksne izloženosti riziku. Stepen i oblik izloženosti riziku se obično procenjuju korišćenjem regresionih modela, tj. procenom parcijalnih regresionih koeficijenata (Adler \& Dumas, 1984; Bartram, 2004).

Objašnjenje uticaja oblika veze između $p$ i $V$ na finansijsku opravdanost upravljanja rizikom se obično zasniva na Jensenovoj nejednakosti (Smith \& Stulz, 1985; MacKay \& Moeller, 2007). Ova nejednakost, u svom najjednostavnijem obliku, predstavlja dokaz da je konveksna (konkavne) funkcija očekivane vrednosti neke promenljive manja (veća) od očekivane vrednosti konveksne (konkavne) funkcije te promenljive. Prema tome, upravljanje rizikom ne doprinosi povećanju vrednosti preduzeća (izloženost riziku povećava vrednost preduzeća) kada je $V_{p p}<0$, jer je tada $V(\bar{p}) \leq E[V(p)]$, gde je $V(\bar{p})$ vrednost preduzeća pod pretpostavkom ostvarenja očekivanih cena (izraz sigurnog ishoda), a $E[V(p)]$ vrednost preduzeća pod pretpostavkom odstupanja stvarnih od očekivanih cena (izraz izloženosti riziku). Upravljanje rizikom je opravdano ako je $V_{p p}>0$, jer je tada $V(\bar{p}) \geq E[V(p)]$. S tim u vezi, P. MacKay i S. B. Moeller (2007) ističu da je vrednost upravljanja rizikom (VUR) moguće utvrditi na sledeći način:

$V U R=V(\bar{p})-E[V(p)]=$

$=V(\bar{p})-\left(V(\bar{p})+\frac{1}{2} V_{p p} \sigma_{p p}\right)=-\frac{1}{2} V_{p p} \sigma_{p p}$

gde je $\sigma_{p p}$ standardna devijacija cene $p_{i} \cdot E[V(p)]$ je određeno vrednošću $V(\bar{p})$ i promenama $V$ (dodatni dobici ili gubici) uzrokovanim neočekivanim promenama $p_{i}$. Formula (3) ukazuje na to da VUR ima pozitivnu vrednost kada je $V_{p p}<0$ (uvek važi $\sigma_{p p} \geq 0$ ), kao i da se $V U R$ povećava sa povećanjem konkavnosti funkcije $V(p)$ i povećanjem promenljivosti $p_{i}$. S obzirom na to da $V$ zavisi od niza cena $p_{i^{\prime}}$ potrebno je proceniti oblik svake funkcije $V\left(p_{i}\right)$. Takođe, budući da je vrednost preduzeća određena očekivanim novčanim prilivima i odlivima, čija je veza sa promenama $p$ pozitivna (prilivi i odlivi se povećavaju sa povećanjem cena), može se zaključiti da će uticaj rizika na $E[V(p)]$ biti pozitivan (negativan) ako su prilivi konveksna (konkavna), a odlivi konkavna (konveksna) funkcija tržišnih cena.

Uticaj oblika veze između $V$ i $p$ na finansijsku opravdanost upravljanja rizikom može biti dodatno grafički objašnjen. Na Slici 2 su predstavljene osnovne veze (oblici izloženosti) između promena $p$ i $V$, pri čemu su na Slici 2 a) predstavljene veze pod pretpostavkom da $V_{p}$ ima pozitivnu vrednost, a na Slici 2 b) pod pretpostavkom da $V_{p}$ ima negativnu vrednost. U nastavku će biti analizirane samo veze na Slici 2 a), budući da se od veza na Slici 2 b) razlikuju samo po pravcu nagiba, a ne obliku veze.

Linijom 3 Slike 2 a) prikazana je linearna izloženost riziku, koja ukazuje na to da se $V$ povećava sa povećanjem $p \mathrm{u}$ istom stepenu $\mathrm{u}$ kojem se smanjuje sa smanjenjem $p$ (preduzeće u povoljnim okolnostima dobija onoliko koliko gubi u nepovoljnim okolnostima). Vrednost preduzeća je određena promenama, a ne promenljivošću $p$ (izloženost jednaka jedinici), pa se može zaključiti da upravljanje rizikom ne utiče na vrednost preduzeća. P. Friberg (1999, 28-29), međutim, smatra da $\mathrm{u}$ analizu uticaja linearne izloženosti riziku na finansijsku opravdanost upravljanja rizikom treba uvesti odnos investitora prema riziku. Tako, ukoliko preduzeće ima jednog vlasnika, koji je indiferentan prema riziku (nulta averzija prema riziku), upravljanje rizikom neće doprineti povećanju vrednosti preduzeća, ako je izloženost linearna. Ako vlasnik ima averziju prema riziku (konkavna funkciju korisnosti), onda će biti manje zadovoljan povoljnim, nego što je nezadovoljan nepovoljnim ishodima. Vlasnik sa averzijom prema riziku uvek prednost daje sigurnom $\mathrm{u}$ odnosu na neizvesni prinos (ako su oni iste vrednosti), pa upravljanje rizikom može doprineti povećanju vrednosti kada je izloženost linearna (vlasnik želi da izloženost bude horizontalna). Ako preduzeće ima veliki broj vlasnika, od kojih svaki može diverzifikovati svoj portfolio, upravljanje rizikom opet ima opravdanja zato što preduzeća imaju mnogo više informacija o izloženosti riziku nego investitori (asismetrične informacije). R. Friberg zaključuje da preduzeća sa linearnom izloženošću riziku treba 


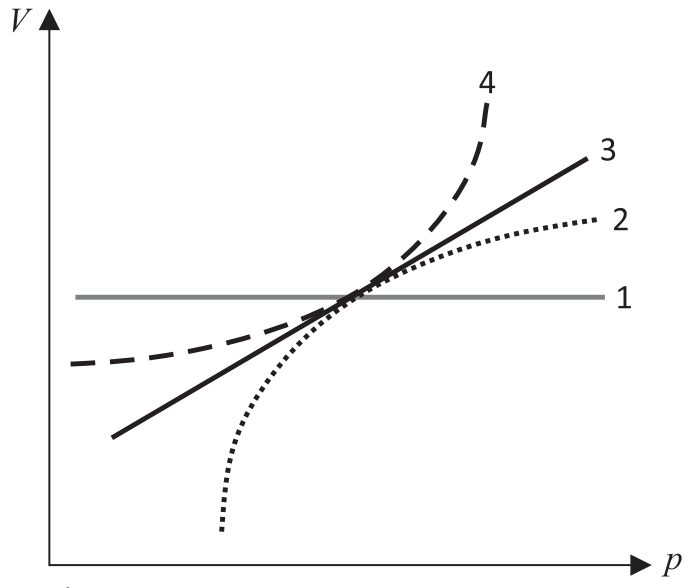

a) $V_{p}>0$

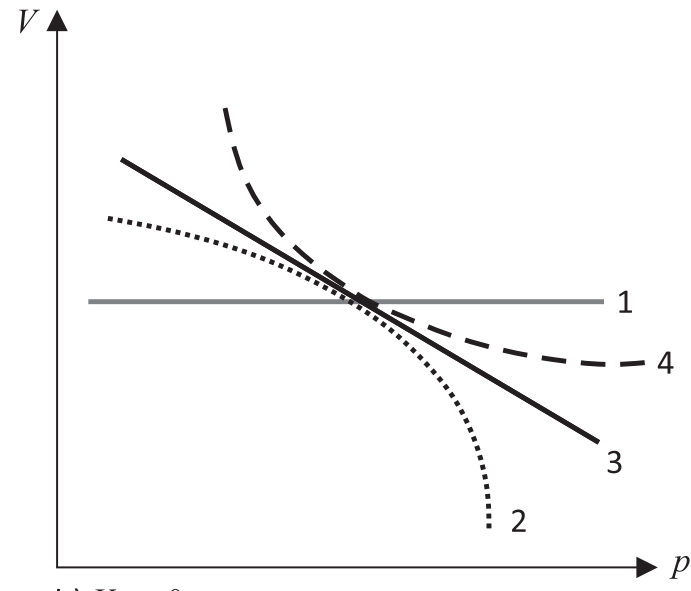

b) $V_{p}>0$

Slika 2 Osnovne relacije između tržišnih cena i vrednosti preduzeća

Izvor: Autor, na osnovu Friberg, 1999, 58

da upravljaju rizikom, osim ako je njihova vrednost veoma velika u odnosu na njihovu izloženost (ukupna vrednost pozicija izloženih riziku).

Linijom 2 Slike 2 a) je prikazana konkavna veza $V$ i $p$, koja je najčešće rezultat delovanja tržišnih nesavršenosti (troškovi finansijskih teškoća, agencijski troškovi i troškovi poreza), čiji se uticaj na $V$ povećava sa povećanjem promenljivosti $v$. Konkavna veza, takođe, može biti rezultat delovanja faktora poput opadajuće korisnosti tehnologije ili rastućih marginalnih troškova proizvodnje (Friberg, 1999, 2628; Bartram, 2000). Konkavna veza ukazuje na to da se $V$ povećava sa povećanjem $p$ u manjem stepenu nego što se smanjuje sa smanjenjem $p$. Drugim rečima, $\mathrm{u}$ skladu sa Jensenovom nejednakošću, $V$ se smanjuje sa povećanjem promenljivosti $p$, pa upravljanje rizikom može usloviti povećanje $V$.

Kao što se na Slici 3 može videti, upravljanje rizikom doprinosi povećanju očekivane vrednosti preduzeća sa $E\left(V_{1}\right)$ na $E\left(V_{2}\right)$ i smanjenju verovatnoće nastupanja finansijskih teškoća (levi kraj raspodele), zahvaljući pomeranju krive raspodele verovatnoća udesno i smanjenju opsega varijacija $V$ (izduživanje raspodele).

Horizontalna linija 1 Slike 2 a) označava situaciju nulte izloženosti preduzeća $\left(V_{p}=0\right)$, što znači da promene $p$ nemaju nikakav uticaj na $V$. Linijom 4 Slike 2 a) je predstavljena konveksna veza $V \mathrm{i} p$, koja ukazuje na to da se $V$ povećava sa rastom $p$ u većem stepenu nego što se smanjuje sa smanjenjem $p$. Ovakva veza ograničava negativni uticaj nepovoljnih promena $p$, tako da se $V$ povećava sa povećanjem promenljivosti $p$ (slično kao kod finansijskih opcija). Konveksna veza može biti rezultat delovanja različitih faktora, mada je to najčešce upravljačka fleksibilnost (na primer, realna opcija proširenja kapaciteta), koja omogućava korigovanje ranije donetih odluka ili izabranih strategija $u$ skladu sa novim okolnostima. Može se zaključiti da upravljanje rizikom ima za cilj da stabilizuje novčane tokove i vrednost korporacije, kako bi se smanjili troškovi izazvani tržišnim nesavršenostima i konkavna izloženost zamenila linearnom, odnosno, da poveća upravljačku fleksibilnost, kako bi se ostvarila konveksna izloženost.

\section{EFEKTI UPRAVLJANJA RIZIKOM}

Ako tržište nije potpuno efikasno (postoje tržišne nesavršenosti), tako da je izloženost riziku konkavna, upravljanje rizikom može doprineti povećanju 


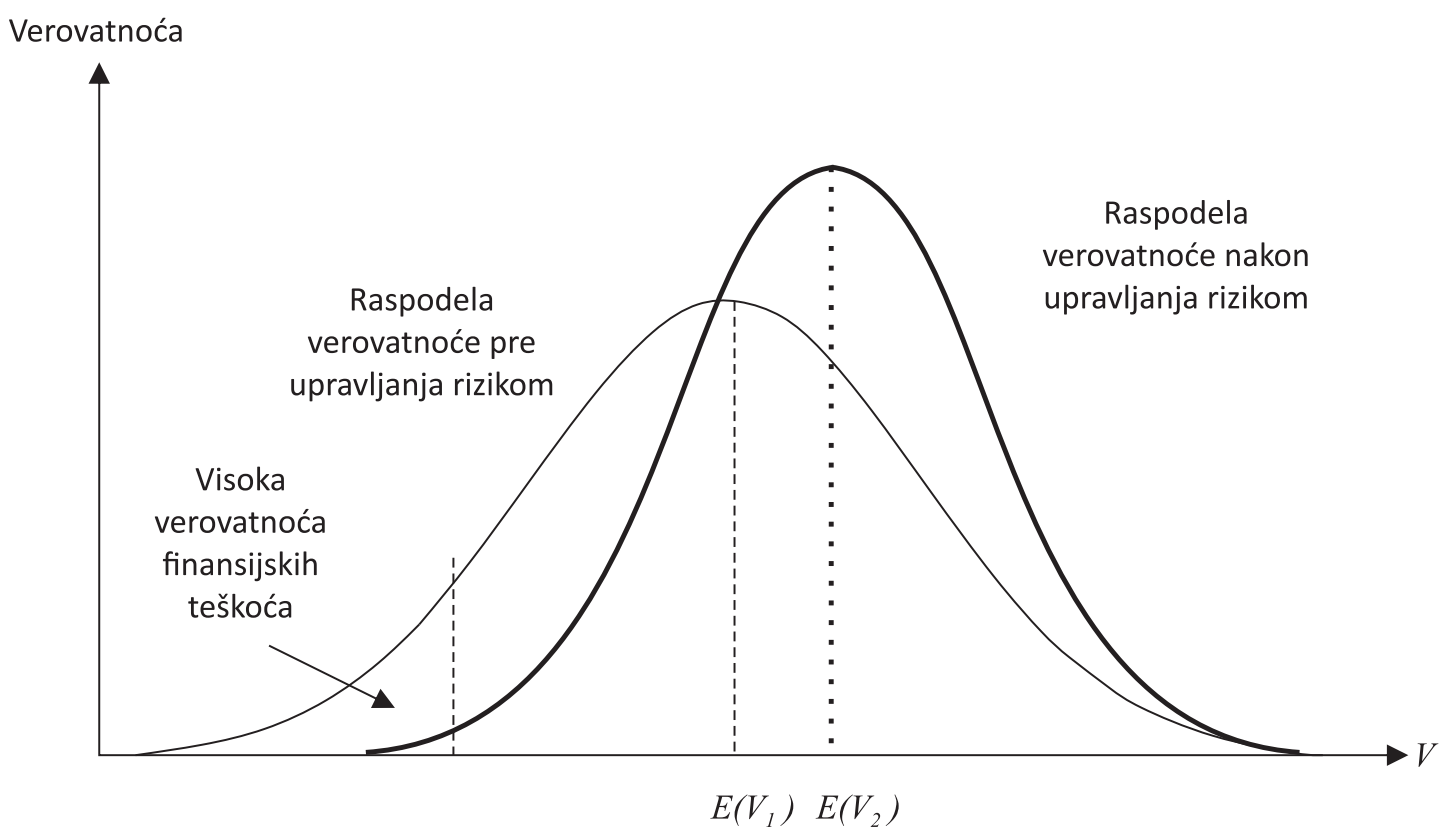

Slika 3 Uticaj upravljanja rizikom na očekivanu vrednost preduzeća

Izvor: Autor, na osnovu Bartram, 2000

vrednosti korporacije na tri osnovna načina (Froot et al, 1994; Fatemi \& Luft, 2002; Graham \& Rogers, 2002):

- smanjenjem troškova finansijskih teškoća (uključujući troškove stečaja),

- smanjenjem agencijskih troškova i

- smanjenjem poreskih obaveza.

Snažne i nepredvidive promene vrednosti novčanih tokova preduzeća, izazvane promenama tržišnih cena, mogu usloviti finansijske teškoće, naročito u preduzećima sa visokim učešćem dugova u finansijskoj strukturi, niskom profitabilnošću i niskom likvidnošću. Ako se neto novčani tok preduzeća smanji toliko da ono ne može na vreme i u punom iznosu da izmiri obaveze prema kreditorima, na efikasnom tržištu će doći do besplatnog transfera imovine od vlasnika ka kreditorima. Na neefikasnom tržištu, finansijske teškoće izazivaju troškove sukoba između vlasnika i kreditora, odbojnost kupaca i dobavljača prema saradnji sa preduzećem, poskupljenje eksternih izvora finansiranja (što izaziva rast troškova propuštenih prinosa, zbog nemogućnosti finansiranja nameravanih ulaganja) i nezadovoljstvo zaposlenih i menadžera (oni gube motivaciju, zahtevaju više naknade, napuštaju preduzeće i slično) (Smith \& Stulz, 1985; Nance, Smith \& Smitson, 1993; Aretz, Bartram \& Dufey, 2007). Ako uslove pokretanje stečajnog postupka, finansijske teškoće izazivaju troškove sudskih taksi i naknada trećim licima (advokati, veštaci i slično).

Efikasno upravljanje rizikom može smanjiti ili otkloniti troškove finansijskih teškoća i povećati vrednost korporacije, ako smanji promenljivost očekivanih novčanih tokova i verovatnoću značajnog smanjenja vrednosti korporacije (Slika 3). Ako upravljanje rizikom otkloni mogućnost nastupanja teškoća, onda će vrednost korporacije porasti za sadašnju vrednost očekivanih troškova finansijskih teškoća pod pretpostavkom da korporacija ne upravlja rizikom, utvrđenu kao proizvod troškova finansijskih teškoća i verovatnoće njihovog nastupanja (Nance et al, 1993). Smanjenjem verovatnoće nastupanja finansijskih teškoća, upravljanje rizikom povećava kapacitet zaduživanja korporacije, što joj omogućava da se 
zadužuje pod povolinijim uslovima i da ostvari poreske uštede (rashodi kamate umanjuju oporezivi dobitak) (Froot, Scharfstein \& Stein, 1993; Damodaran, 2008, 325-326). Povećanje kapaciteta zaduživanja i smanjenje cene dugova uslovljava smanjenje ponderisane prosečne cene kapitala (kriterijuma isplativosti ulaganja), tako da će više alternativa ulaganja moći da doprinese povećanju vrednosti korporacije.

Na neefikasnom tržištu, koje karakterišu nesavršeni ugovori i asimetrične informacije, agencijski troškovi se pretežno javljaju u vezi sa dva problema:

- nedovoljno i rizično ulaganje, kao izraz sukoba između akcionara i poverilaca i

- averzija menadžera prema riziku i visoke menadžerske naknade, kao izraz sukoba između akcionara i menadžera.

Problem nedovoljnog ulaganja (underinvestment) nastaje kada akcionari odustaju od ulaganja sa pozitivnom neto sadašnjom vrednošću, ako takva ulaganja najveće koristi donose kreditorima (Myers, 1977). Ovaj problem je svojstven korporacijama sa visokim iznosom rizičnih dugova i niskom vrednošću ukupne imovine, za čije akcionare ostaje malo ili nimalo slobodnog novčanog toka nakon izmirenja fiksnih obaveza prema kreditorima. Budući da rearanžiranje ugovorenih kredita i smanjenje stepena zaduženosti može biti skupo (dodatne ugovorne klauzule, gubitak poreskih ušteda i slično), upravljanje rizikom može biti jeftinije rešenje ovog problema. Upravljanje rizikom smanjuje promenljivost vrednosti korporacije i verovatnoću da će se ona smanjiti ispod nivoa koji će akcionare podstaći da odustanu od ulaganja sa pozitivnom neto sadašnjom vrednošću (Nance et al, 1993). Ono smanjuje nestabilnost internih izvora finansiranja i rizik da neće biti dovoljni da omoguće finansiranje ulaganja sa pozitivnom neto sadašnjom vrednošću. Ako interni izvori nisu dovoljni, rastu oportunitetni troškovi propuštenih prinosa ako korporacija odustane od ulaganja ili ponderisana prosečna cena kapitala ako korporacija angažuje dodatne eksterne (sopstvene i pozajmljene) izvore finansiranja (interni su jeftiniji od eksternih izvora finansiranja, naročito kada je korporacija izložena visokim troškovima finansijskih teškoća i agencijskim troškovima) (Froot et al, 1993).
Sukob interesa akcionara i poverilaca, takođe, može nastati ako akcionari prednost daju veoma rizičnim $u$ odnosu na manje rizična ulaganja, čak i kada je njihova neto sadašnja vrednost negativna (asset substitution) (Myers, 1977). Rezidualno pravo akcionara na novčane tokove preduzeća (akcionari imaju pravo na novčane tokove preduzeća, pošto ono izmiri obaveze prema ostalim interesnim grupama) ima osobine kupovne opcije na imovinu preduzeća, čija je cena realizacije jednaka vrednosti ukupnog pozajmljenog kapitala. Budući da se vrednost opcije povećava sa povećanjem rizičnosti imovine $\mathrm{u}$ njenoj osnovi, vrednost za akcionare će se povećati ako oni manje rizična ulaganja zamene veoma rizičnim ulaganjima. Ako poverioci očekuju ovakvo ponašanje akcionara, oni mogu zahtevati više prinose ili ugovaranje zaštitnih klauzula, što povećava agencijske troškove i smanjuje vrednost korporacije. Upravljanje rizikom smanjuje promenljivost vrednosti korporacije i verovatnoću da će akcionari preduzimati rizične poduhvate (manja je verovatnoća da će vrednost dugova biti veća od vrednosti korporacije), pa će poverioci biti spremni da korporaciji ponude bolje uslove pozajmice. Kako ne postoji garancija da će korporacija koje trenutno upravlja rizikom i u budućnosti upravljati rizikom, poverioci mogu ponuditi nižu kamatnu stopu samo korporacijama koja istovremeno ugovore kredit i program upravljanja rizikom (Aretz \& Bartram, 2010).

Sukob između menadžera i akcionara može nastupiti ako menadžeri, kako bi maksimirali sopstveno blagostanje, preduzimaju aktivnosti koje ne moraju biti u skladu sa interesima akcionara, niti sa ciljem maksimiranja vrednosti korporacije. Ovaj sukob je naročito izražen ako menadžeri sa visokom averzijom prema riziku imaju visok udeo u vlasništvu, tako da nastupanjem finansijskih teškoća mogu izgubiti sve tekuća i buduća primanja (plata, dividenda i kapitalni dobitak), ugled i mogućnost napredovanja (Meulbroek, 2002). Kako bi smanjili stepen svoje izloženosti riziku i povećali svoje blagostanje, menadžeri mogu preduzimati aktivnosti sa negativnom neto sadašnjom vrednošću (na primer, konglomeratska diverzifikacija i izbor suboptimalne strukture kapitala), koje uslovljavaju smanjenje blagostanja akcionara. Kako bi interese menadžera uskladili sa svojim interesima, akcionari će biti primorani da pojačaju nadzor nad 
njihovim radom i povećaju njihove plate i bonuse, što uslovljava rast agencijskih troškova i dodatno smanjenje vrednosti korporacije.

Upravljanje rizikom može smanjiti agencijske troškove i povećati vrednost korporacije ako smanji rizik profitabilnih ulaganja, tj. uskladi preferencije (stepen averzije prema riziku) i interese menadžera i akcionara. Menadžeri će, tada, zahtevati niže naknade i biti manje skloni da preduzimaju skupe strategije smanjenja rizika kojima su izloženi (Bartram, 2000). Smanjenje rizika ulaganja u korporaciju će, takođe, podstaći akcionare da povećaju svoje učešće u vlasništvu (koncentracija vlasništva), što će povećati efektivnost njihovog nadzora nad radom menadžera. Oni će zahtevati i niže stope prinosa, što će se neposredno odraziti na povećanje vrednosti korporacije. Akcionari mogu podesiti stepen averzije menadžera prema riziku primenom različitih sistema nagrada za njihove rezultate (Geczy, Minton \& Schrand, 1997; Coles, Daniel \& Naveen, 2006). Tako, programi učešća menadžera u vlasništvu i vezivanje nagrada menadžera za promene cena akcija uslovljavaju konkavnu funkciju očekivane korisnosti blagostanja menadžera u odnosu na očekivanu vrednost korporacije (izraz averzije menadžera prema rizika), pa menadžeri mogu biti skloni da prekomerno smanje izloženost korporacije rizicima. Programi nagrađivanja menadžera kupovnim opcijama na obične akcije uslovljavaju konveksnu funkciju očekivane korisnosti blagostanja menadžera (izraz sklonosti menadžera prema riziku), pa oni mogu biti skloni da povećaju izloženost korporacije rizicima, kako bi povećali vrednost svojih opcija i svoje blagostanje.

Kada je porez na dobitak konveksna funkcija oporezivog dobitka (poreska obaveza raste brže nego što raste dobitak, a smanjuje se sporije nego što se smanjuje dobitak), tada je vrednost korporacije konkavna funkcija oporezivog dobitka (vrednost korporacije raste sporije nego što raste dobitak, a smanjuje se brže nego što se smanjuje dobitak). U zoni veoma visokog dobitka, konveksnost poreske obaveze može biti uslovljena progresivnom poreskom stopom, jer se poreska obaveza više nego proporcionalno povećava sa rastom dobitka. U zoni gubitka ili niskog dobitka, ona može biti uslovljena vremenskim ograničenjima za prenos gubitaka utvrđenih poreskim bilansom i/ili poreskog kredita (po osnovu ulaganja ili poreza plaćenog $u$ inostranstvu) na naredne periode. Tada, korporacija ne može u potpunosti iskoristiti ove poreske pogodnosti, pa se poreska obaveza ne može u dovoljno kratkom roku smanjiti (sadašnja vrednost neiskorišćenih poreskih pogodnosti se smanjuje sa protokom vremena, time i efekti njihovog korišćenja) (Geczy et al, 1997). Kada je funkcija poreza konveksna, promenljivi dobitak će za posledicu imati veću prosečnu poresku obavezu nego stabilni dobitak, jer izuzetno visoki dobici podrazumevaju plaćanje visokog poreza, a niski dobici ograničavaju korišćenje poreskih pogodnosti. Ako uspe da ograniči promene dobitka na određeni optimalni opseg bez ekstremnih vrednosti, upravljanje rizikom može smanjiti poresku obavezu (Froot et al, 1993; Graham \& Rogers, 2002). Tada će uštede zbog manje plaćenog poreza $u$ periodima visokog dobitka biti veće od gubitaka zbog više plaćenog poreza $u$ periodima nižeg dobitka. Upravljanje rizikom može smanjiti poresku obavezu i povećanjem kapaciteta zaduživanja, što je objašnjeno kao efekat smanjenja troškova finansijskih teškoća.

\section{OPTIMALNA IZLOŽENOST RIZIKU}

Ako je funkcija vrednosti preduzeća konkavna, investitori mogu zahtevati da menadžeri u potpunosti otklone ili minimiziraju izloženost riziku, što odgovara stavu da oni imaju visok stepen averzije prema riziku (averzija teži beskonačnosti). Međutim, s obzirom na veoma visoke troškove takvog pristupa, verovatnije je da će investitori od menadžera zahtevati da ukupnu izloženost riziku svedu na optimalni nivo (to može da bude nulta izloženost), koji omogućava maksimiranje vrednosti korporacije. Optimalni ili prihvatljivi nivo izloženosti se često utvrđuje $u$ zavisnosti od željenog rejtinga obveznica korporacije, koji odražava verovatnoću da će ona zapasti u finansijske teškoće (Nocco \& Stulz, 2006). Ako očekuje da će pad rejtinga obveznica usloviti značajno povećanje cene kapitala iz ovog izvora i smanjenje vrednosti korporacije, menadžment može doneti odluku da poveća napore $\mathrm{u}$ domenu upravljanja rizikom, kako bi smanjio verovatnoću takvog ishoda. Prema tome, menadžment može odrediti veličinu ulaganja u upravljanje rizikom, tako da dostigne određeni kreditni rejting obveznica, 
pri kojem ce maksimirati vrednost korporacije. Ulaganja će biti veća ako korporacija ima više razvojnih mogućnosti, koje neće moći da realizuje ako cena kapitala od obveznica poraste. Zrela korporacija sa manje razvojnih mogućnosti će manje ulagati u upravljanje rizikom, jer više vrednosti za svoje vlasnike može stvoriti povećanjem stepena zaduženosti i korišćenjem poreskih ušteda. Budući da učešće sopstvenog kapitala u strukturi kapitala, takođe, značajno određuje rejting obveznica, menadžment može smanjiti ulaganja $u$ upravljanje rizikom ako poveća učešće sopstvenog kapitala (učešće kapitala i upravljanje rizikom su supstituti). Takva odluka će biti finansijski opravdana ako se troškovi upravljanja rizikom smanje u iznosu većem od povećanja troškova ukupnog kapitala (sopstveni kapital je skuplji od pozajmljenog).

Kako bi odredili optimalni nivo izloženosti riziku na nivou preduzeća, H. Shin i R. M. Stulz (2000) su $\mathrm{u}$ analizu uveli trošak držanja nehedžiranog rizika $\left(C_{n h r}\right)$ i trošak hedžinga $\left(C_{h}\right)$. Nehedžirani je rizik koji preostane nakon hedžinga, tj. upravljanja rizikom. Trošak $C_{h}$ nastaje $\mathrm{u}$ vezi sa korišćenjem finansijskih derivata (forvardi, fjučersi, opcije i slično), čiji su transakcioni troškovi relativno niski. Budući da je neke rizike teže otkloniti, nakon određenog nivoa, dodatno inkrementalno smanjenje nehedžiranog rizika postaje veoma skupo. Ukupni trošak držanja nehedžiranog rizika $\left(T C_{n h r}\right)$ je jednak zbiru $C_{n h r}$ i $C_{h}$. H. Shin i R. M. Stulz su zaključili da je optimalni nivo nehedžiranog rizika dostignut kada preduzeće minimizira $T C_{n h r}$, tj. kada izjednači marginalni trošak držanja nehedžiranog rizika $\left(M C_{n h r}\right)$ i marginalni trošak hedžinga $\left(M C_{h}\right)$. Treba primetiti da je $M C_{n h r}$ rastuća, a $M C_{h}$ opadajuća funkcija nehedžiranog rizika (Slika 4). H. Shin i R. M. Stulz su, dalje, analizirali vrednost preduzeća sa istim funkcijama $M C_{h^{\prime}}$ ali različitim funkcijama $M C_{n h r}$. Zaključili su da će preduzeće sa višim $M C_{n h r}$ imati niži nivo nehedžiranog rizika i manju vrednost zbog višeg $T C_{n h r}$, što znači da je moguće da preduzeće sa više nehedžiranog rizika ima višu vrednost. Ako delovanjem nekog spoljašnjeg faktora nehedžirani rizik preduzeća značajno poraste, kriva $M C_{h}$ će se pomeriti udesno (trošak marginalnog smanjenja rizika ostaje nepromenjen), dok će kriva
$M C_{n h r}$ ostati nepromenjena. Tada će $T C_{n h r}$ porasti, uslovljavajući smanjenje vrednosti preduzeća i porast optimalnog nivoa nehedžiranog rizika.

U skladu sa analizom H. Shin-a i R. M. Stulz-a, može se zaključiti da upravljanje rizikom na nivou korporacije ima smisla sve dok ono izaziva veće koristi (smanjenje troškova tržišnih nesavršenosti) od troškova. Kao tipični eksplicitni trošak upravljanja rizikom, A. Damodaran (2008, 320-321) navodi premiju osiguranja, koju preduzeća plaćaju kako bi se osigurala od različitih rizika. Ovaj trošak je viši ako osiguranje pruža potpunije pokriće rizika i ako su verovatnoća nastupanja i očekivani uticaj rizika veći. Preduzeća koja koriste finansijske opcije plaćaju eksplicitni trošak premije (cena opcije). Preduzeća ne plaćaju eksplicitni, ali se suočavaju sa mogućim implicitnim troškom korišćenja finansijskih forvarda i fjučersa. Ako preduzeće kupi fjučers kako bi se zaštitilo od pada cena svojih proizvoda, propustiće da ostvari viši dobitak (implicitni trošak) ako cena poraste. U finansijskoj literaturi se ističe da su troškovi upravljanja rizikom raznovrsni, ali relativno niski, čak i na veoma neefikasnim tržištima (Bartram, 2000; Stephens, 2001, 27). Zato je malo verovatno da će

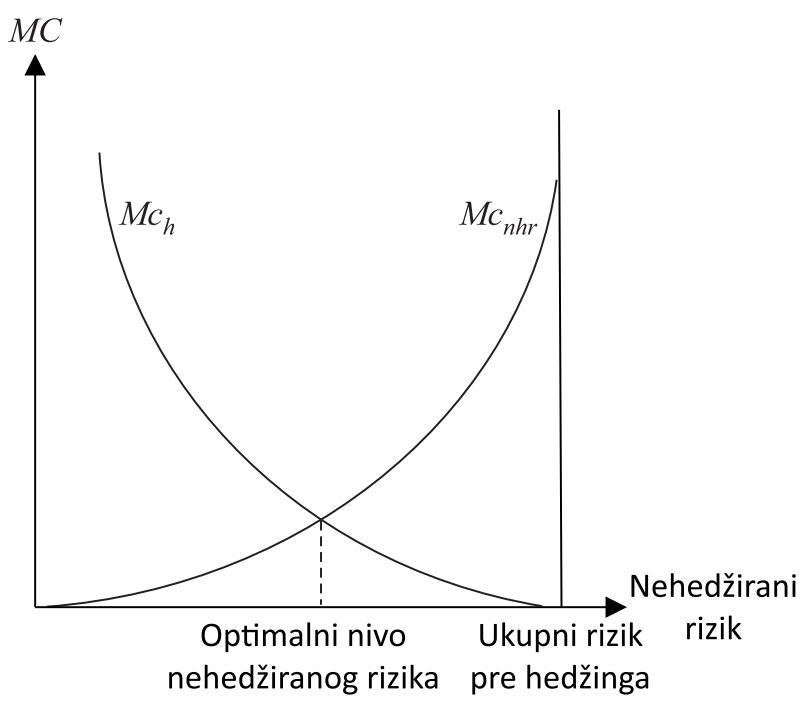

Slika 4 Optimalni nivo nehedžiranog rizika

Izvor: Shin \& Stulz, 2000 
troškovi prevazići koristi od upravljanja rizikom pri visokim nivoima rizika, što bi bio dovoljan razlog da preduzeće prihvati ukupni rizik. J. J. Stephens (2001, 27) upozorava da je prihvatanje ukupnog ili visok nivoa rizika špekulativna strategija, koja zahteva pažljivu proveru informacija i predviđanja pre njenog izbora, kao i stalno praćenje nakon izbora kako bi, u slučaju da se situacija ne razvija kako je očekivano, bila preduzeta korektivna akcija.

R. M. Stulz (1996) je u analizu optimalne izloženosti riziku uveo komparativnu prednost preduzeća $u$ prihvatanju rizika, kako bi ukazao na razloge za selektivno upravljanje rizikom. Preduzeće poseduje komparativnu prednost ako, u odnosu na investitore i druga preduzeća, ima bolji pristup tržišnim informacijama značajnim za predviđanje promena određenih tržišnih cena. Tako, ako preduzeće poseduje komparativnu prednost u prihvatanju deviznog rizika, menadžment može povećati izloženost preduzeća tom riziku, jer može pravovremeno i efikasno odgovoriti na nepovoljne (na primer, korišćenjem valutnih forvarda) i iskoristiti povoljne (zauzimanjem nehedžirane pozicije) promene deviznih kurseva. Istovremeno će povećati ulaganja u upravljanje ostalim rizicima, kako bi smanjio verovatnoću njihovog nepovoljnog uticaja na vrednost preduzeća. Kako bi smanjio verovatnoću ostvarenja gubitaka od selektivnog upravljanja rizikom, menadžment treba pažljivo da proceni komparativnu prednost preduzeća. Ako ima veliko tržišno učešće i ostvaruje veliki promet na deviznom tržištu, raste verovatnoća da će preduzeće imati komparativnu prednost na tom tržištu, a smanjuje se verovatnoća ostvarenja gubitaka. Treba primetiti da komparativna prednost preduzeća daje menadžmentu fleksibilnost $\mathrm{u}$ odlučivanju (realne opcije), tako da izloženost odgovarajućem riziku postaje konveksna.

\section{ZAKLJUČAK}

Polazeći od osnovnih teorijskih pretpostavki o efikasnosti tržišta i averziji investitora prema riziku, $\mathrm{u}$ radu su analizirani teorijski argumenti o uticaju upravljanja rizikom na vrednost korporacije. Ako se pretpostavi da je tržište savršeno efikasno, a investitori potpuno racionalni, onda upravljanje rizikom na nivou korporacije nije finansijski opravdano, jer investitori diverzifikacijom mogu sami uspešnije otkloniti rizik svojih ulaganja. Međutim, ako se u obzir uzmu tržišne nesavršenosti i izbori koje investitori stvarno čine u uslovima neizvesnosti, onda se zaključci o upravljanju rizikom menjaju. Tržišne nesavršenosti, poput troškova finansijskih teškoća, agencijskih troškova i oporezivanja, mogu usloviti razvoj konkavne izloženosti rizicima. U skladu sa Jensenovom nejednakošću, upravljanje rizikom će usloviti smanjenje troškova tržišnih nesavršenosti i doprineti povećanju vrednosti korporacije čija je izloženost riziku konkavna. Ako je averzija investitora prema riziku izražena, onda upravljanje rizikom na nivou korporacije može biti opravdano, čak i kada je izloženost riziku linearna. S tim u vezi, zaključak je da treba prihvatiti prvu hipotezu ovog rada.

U finansijskoj literaturi se često analizira problem procene optimalnog stepena izloženosti riziku korporacije. Rešenje ovog problema je pretežno određeno averzijom investitora prema riziku, troškovima upravljanja rizikom i komparativnom prednošću korporacije na relevantnom tržištu. Iako je moguće da će korporacija u potpunosti otkloniti izloženost pojedinih pozicija nekom riziku, ono verovatno neće potpuno otkloniti izloženost svih pozicija istom riziku. Korporacija će nastojati da izloženost određenom riziku svede na nivo pri kojem su ukupni troškovi upravljanja rizikom minimalni, tj. pri kojem se izjednačavaju marginalni troškovi držanja nehedžiranog rizika i marginalni troškovi upravljanja rizikom. S obzirom na to da su troškovi upravljanja rizikom relativno niski, a potencijalne koristi upravljanja rizikom velike, malo je verovatno da će korporacija doneti odluku da uopšte ne upravlja rizikom, tj. da prihvati ukupni rizik promene određene tržišne cene. Konačno, korporacija će doneti odluku da prihvati viši nivo određenog rizika ako poseduje komparativnu prednost u prihvatanju tog rizika, mada treba primetiti da, tada, izloženost korporacije postaje konveksna. Radom su navedeni argumenti u prilog stavu da menadžment može maksimirati vrednost korporacije ako optimizira njenu izloženost, tako je potvrđena i druga hipoteza rada.

Dva su doprinosa ovog rada. Prvo, sprovedeno teorijsko istraživanje doprinosi daljem razvoju teorijskih i 
empirijskih modela o uticaju oblika izloženosti riziku na finansijsku opravdanost upravljanja rizikom na nivou korporacije (Smith \& Stulz, 1985; MacKay \& Moeller, 2007). U radu je razvijen opšti pristup oceni opravdanosti upravljanja rizikom, koji u obzir uzima stepen, oblik i pravac veze između vrednosti (preduzeća, imovine, obaveza itd.) i različitih faktora rizika, kao i stepen averzije investitora prema riziku. Drugo, uključivanjem troškova upravljanja rizikom i troškova nehedžiranog rizika $u$ analizu finansijske opravdanosti upravljanja rizikom, ovaj rad doprinosi daljem razvoju teorijskih stavova o optimalnom stepenu izloženosti riziku. Isticanjem komparativne prednosti korporacije na relevantnom tržištu, u analizu se posredno uključuju realne opcije, kao izraz poslovnih strategija upravljanja rizikom. Teorijski pristup razvijen $u$ radu predstavlja dobru osnovu za buduća teorijska i empirijska istraživanja, ali ima ograničenu praktičnu vrednost jer ne objašnjava konkretne modele za ocenu finansijske opravdanosti upravljanja rizikom. Ipak, ovaj pristup može poslužiti kao osnova za razvoj smernica i modela, koji će menadžerima pomoći da donesu prave odluke $u$ stvarnom poslovnom okruženju.

U teorijskim istraživanjima se obično pretpostavlja da korporacija rizikom upravlja koristeći finansijske derivate, dok se zanemaruje značaj strategija poslovnog upravljanja rizikom. Ovaj problem je u radu samo nagovešten, isticanjem da preduzeće može postići konveksnu izloženost riziku ukoliko, razvojem realnih opcija, poveća stepen svoje poslovne fleksibilnosti. Preduzeće sa realnim opcijama može ublažiti uticaj nepovoljnih i iskoristiti povoljne promene tržišnih cena $u$ cilju maksimiranja vrednosti. S tim $u$ vezi, buduća istraživanja treba pažnju da usmere na analizu uticaja poslovnih strategija upravljanja rizikom na vrednost korporacije. Empirijska istraživanja uticaja finansijskih strategija upravljanja rizikom na vrednost korporacije u razvijenim zemljama ne pružaju uvek potvrdu teorijskih zaključaka (Graham \& Rogers, 2002; Aretz et al, 2007). Razloge za takve empirijske nalaze treba delimično tražiti u neadekvatno postavljenim empirijskim modelima, koji analiziraju samo jedan aspekt upravljanja rizikom (na primer, samo trošak finansijskih teškoća). Zato, buduća empirijska istraživanja, naročito $\mathrm{u}$ privredama sa nedovoljno razvijenim tržištima, treba da uvaže kompleksnost izloženosti riziku i upravljanja rizikom, kako bi omogućila pouzdanu ocenu teorijskih zaključaka.

\section{REFERENCE}

Adler, M., \& Dumas, B. (1984). Exposure to currency risk: definition and measurement. Financial Management, 13(2), 41-50. doi: $10.2307 / 3665446$

Aretz, K., \& Bartram, S. M. (2010). Corporate hedging and shareholder value. Journal of Financial Research, 33(4), 317-371. doi: 10.1111/j.1475-6803.2010.01278.x

Aretz, K., Bartram, S. M., \& Dufey, G. (2007). Why hedge? Rationales for corporate hedging and value implications. Journal of Risk Finance, 8(5), 434-449. doi: $10.1108 / 15265940710834735$

Bartram, S. M., (2000). Corporate Risk Management as a Lever for shareholder value creation. Financial Markets, Institutions and Instruments, 9(5), 279-324. doi: 10.1111/1468-0416.00038

Bartram, S. M. (2004). Linear and nonlinear foreign exchange rate exposures of German nonfinancial corporations. Journal of International Money and Finance, 23(4), 673-699. doi: 10.1016/j. jimonfin.2004.03.002

Berle, A. A., \& Means, G. C. (1932). The Modern Corporation and Private Property. New York, NY: Macmillan.

Bodnar, G. M., \& Gebhardt, G. (1999). Derivatives usage in risk management by U.S. and German non-financial firms: A comparative survey. Journal of International Financial Management and Accounting, 30(3), 153-187. doi: 10.1111/1467646X.00049

Brown, G. W., Crabb, P. R., \& Haushalter, D. (2006). Are firms successful at selective hedging? Journal of Business, 79(6), 2925-2949. doi: 10.1086/508004

Coles, J. L., Daniel, N. D., \& Naveen, L. (2006). Managerial incentives and risk-taking. Journal of Financial Economics, 79(2), 431-468. doi: 10.1016/j.jfineco.2004.09.004

Damodaran, A. (2008). Strategic Risk Taking: A Framework for Risk Management. Upper Saddle River. NJ: Pearson Education.

Dumas, B. (1978). The theory of trading firm revisited. Journal of Finance, 33(3), 1019-1030. doi: 10.1111/j.1540-6261.1978. tb02041.x

Fatemi, A., \& Luft, C. (2002). Corporate risk management: costs and benefits. Global Finance Journal, 13(1), 29-38. doi: 10.1016/ 
S1044-0283(02)00037-6

Friberg, R. (1999). Exchange Rates and the Firm: Strategies to Manage Exposure and the Impact of EMU. New York, NY: Palgrave Macmillan.

Froot, K. A., Scharfstein, D. S., \& Stein, J. C. (1993). Risk management: coordinating corporate investment and financing policies. Journal of Finance, 48(5), 1629-1658. doi: 10.1111/j.1540-6261.1993.tb05123.x

Froot, K. A., Scharfstein, D. S., \& Stein, J. C. (1994). A framework for risk management. Harvard Business Review, 72(6), 91-102. doi: 10.1111/j.1745-6622.1994.tb00415.x

Geczy, C., Minton, B. A., \& Schrand, C. (1997). Why firms use currency derivatives. Journal of Finance, 52(4), 1323-1354. doi: 10.1111/j.1540-6261.1997.tb01112.x

Graham, J. R., \& Rogers, D. A. (2002). Do firms hedge in response to tax incentives? Journal of Finance, 57(2), 815-839. doi: 10.1111/1540-6261.00443

Jaksic, M. (2012). Risk management of portfolio securities. Economic Horizons, 14(3), 155-168. doi: 10.5937/ekonhor1203151J

Joseph, N. L. (2000). The choice of hedging techniques and the characteristics of UK industrial firms. Journal of Multinational Financial Management, 10(2), 161-184. doi: 10.1016/S1042444X(99)00025-0

Kahneman, D., \& Tversky, A. (1979). Prospect theory: an analysis of decision under risk. Econometrica, 47(2), 263-292. doi: $10.2307 / 1914185$

Mackay, P., \& Moeller, S. B. (2007). The value of corporate risk management. Journal of Finance, 62(3), 1379-1419. doi: 10.1111/j.1540-6261.2007.01239.x

Meulbroek, L. K. (2002). A senior manager's guide to integrated risk management. Journal of Applied Corporate Finance, 14(4), 56-70. doi: 10.1111/j.1745-6622.2002.tb00449.x

Modigliani, F., \& Miller, M. H. (1958). The cost of capital, corporation finance and the theory of investment. American Economic Review, 48(3), 261-297.

Modigliani, F., \& Miller, M. H. (1963). Corporate income taxes and the cost of capital: a correction. American Economic Review, 53(3), 433-443.

Myers, S. C. (1974). Interactions of corporate financing and investment decisions - Implications for capital budgeting. Journal of Finance, 29(1), 1-25. doi: 10.1111/j.1540-6261.1974. tb00021.x

Myers, S. C. (1977). Determinants of corporate borrowing. Journal of Financial Economics, 5(2), 147-175. doi: 10.1016/0304405X(77)90015-0

Myers, S. C., \& Majluf, N. (1984). Corporate financing and investment decisions when firms have information investors do not have. Journal of Financial Economics, 13(2), 187-221. doi: 10.1016/0304-405X(84)90023-0

Nance, D. R., Smith, C. W., \& Smitson, C. W. (1993). On the determinants of corporate hedging. Journal of Finance, 48(1), 267-284. http://doi.org/10.2307/2328889

New York Stock Exchange. (2013). NYSE Listed Company Manual: Corporate Governance Standards s303.A.07(D). New York, US.

Nocco, B. W., \& Stulz, R. M. (2006). Enterprise risk management: theory and practice. Journal of Applied Corporate Finance, 18(4), 8-20. doi: 10.1111/j.1745-6622.2006.00106.x

Organization for Economic Cooperation and Development. (2015). G20/OECD Principles of Corporate Governance. Paris, France.

Sarbanes-Oxley Act of 2002, Pub. L. 107-204, 116 Stat. 745 (codified as amended at 15 U.S.C. $\$ \S 7201-7266$ ).

Sharpe, W. (1964). Capital asset prices: A theory of market equilibrium under conditions of risk. Journal of Finance, 19(3), 425-442. doi: 10.1111/j.1540-6261.1964.tb02865.x

Shin, H., \& Stulz, R. M. (2000). Firm value, risk, and growth opportunities. Working Paper No. 7808. Retreived from National Bureau of Economic Research, website: http:// www.nber.org/papers/w7808.

Smith, C. W., \& Stulz, R. M. (1985). The Determinants of Firms' Hedging Policies. Journal of Financial and Quantitative Analysis, 20(4), 391-405. doi: 10.2307/2330757

Stephens, J. J. (2001). Managing Currency Risk Using Financial Derivatives. Chichester, England: John Wiley and Sons.

Stulz, R. M. (1996). Rethinking risk management. Journal of Applied Corporate Finance, 9(3), 8-24. doi: 10.1111/j.17456622.1996.tb00295.x

Tversky, A., \& Kahneman, D. (1992). Advances in prospect theory: Cumulative representation of uncertainty. Journal of Risk and uncertainty, 5(4), 297-323. doi: 10.1007/BF00122574 
Primljeno 13. novembra 2015, nakon revizije, prihvaćeno za publikovanje 15. decembra 2015. Elektronska verzija objavljena 25. decembra 2015.

Milan Čupić je docent na Ekonomskom fakultetu Univerziteta u Kragujevcu. Na istom Fakultetu je doktorirao u oblasti Međunarodnih poslovnih finansija. Angažovan je na predmetima Poslovne finansije i Finansijsko prestrukturiranje preduzeća. Oblasti njegovog interesovanja su upravljanje deviznim rizikom, analiza troškova i koristi, merenje performansi i korporativno upravljanje.

\title{
RISK MANAGEMENT AND CORPORATE VALUE
}

\author{
Milan Cupic \\ Faculty of Economics, University of Kragujevac, Kragujevac, The Republic of Serbia
}

The paper presents a theoretical framework for assessing the impact of risk management on corporate value. As the relevant factors that determine this impact, the paper analyzes market imperfections and investors' risk aversion. The results of the present research indicate that risk management contributes to an increase in corporate value if, under the influence of market imperfections, corporate risk exposure is concave. As an expression of market imperfections, the paper analyzes the costs of financial distress, agency costs, and taxation. The results of the research also indicate that the risk management policy should not aim to minimize, but rather optimize risk exposure, by taking into account the costs of risk management, investors' risk aversion and the competitive advantage a corporation has on the relevant market.

Keywords: risk management, corporate value, risk exposure, market imperfections, risk aversion

JEL Classification: G14, G32 